\title{
Megaloblastic Hematopoiesis In Vitro \\ Interaction of Anti-Folate Receptor Antibodies with Hematopoietic Progenitor Cells Leads to a Proliferative Response Independent of Megaloblastic Changes
}

\author{
Asok C. Antony, Robert A. Briddell, John E. Brandt, John E. Straneva, Rama S. Verma, \\ Michael E. Miller, Lorrie A. Kalasinski, and Ronald Hoffman \\ Division of Hematology/Oncology, Department of Medicine, Indiana University School of Medicine, Indianapolis, Indiana 46202-5121
}

\begin{abstract}
We tested the hypothesis that anti-placental folate receptor (PFR) antiserum-mediated effects on hematopoietic progenitor cells in vitro of increased cell proliferation and megaloblastic morphology were independent responses. We determined that (a) purified IgG from anti-PFR antiserum reacted with purified apo- and holo-PFR and specifically immunoprecipitated a single (44-kD) iodinated moiety on cell surfaces of low density mononuclear cells (LDMNC); (b) when retained in culture during in vitro hematopoiesis, anti-PFR IgG (in contrast to PFRneutralized anti-PFR IgG and nonimmune IgG) consistently led to increased cloning efficiency of colony forming unit-erythroid (CFU-E), burst forming unit-E (BFU-E), CFU-granulocyte macrophage (CFU-GM), and CFU-GEM megakaryocyte (CFU-GEMM), and objectively defined megaloblastic changes in orthochromatic normoblasts from CFU-E- and BFU-E-derived colonies; $(c)$ when anti-PFR antiserum was removed after initial ( $<1$ h) incubation with LDMNC, a cell proliferation response was induced, but megaloblastic changes were not evident. (d) Conversely, delay at $4^{\circ} \mathrm{C}$ for $24 \mathrm{~h}$ before long-term plating with antiserum resulted in megaloblastosis without increased cell proliferation; $(e)$ however, 500 -fold molar excess extracellular folate concentrations completely abrogated the expected anti-PFR antiserum-induced megaloblastic changes, without altering cell proliferative responses. Thus, although cell proliferative and megaloblastic changes are induced after short-term and prolonged interaction of antibody with folate receptors on hematopoietic progenitors, respectively, they are independent effects. (J. Clin. Invest. 1991. 87:313-325.) Key words: megaloblastosis • folate binding • transport • hyperplasia - bone marrow • morphology
\end{abstract}

\section{Introduction}

Folate deficiency leads to impaired DNA synthesis and megaloblastic hematopoiesis (1-4). However, the cause of the characteristic bone marrow hyperplasia in megaloblastosis remains unclear because cell cycle kinetic data have revealed a slow proliferative rate of megaloblastic cells $(5,6)$, and, it is estimated that $80-90 \%$ of these cells are destroyed within the megaloblastic bone marrow itself (1-4).

\footnotetext{
Address correspondence to Dr. Asok C. Antony.

Received for publication 21 August 1989 and in revised form 4 September 1990.
}

J. Clin. Invest.

(C) The American Society for Clinical Investigation, Inc. $0021-9738 / 91 / 01 / 313 / 13 \quad \$ 2.00$

Volume 87, January 1991, 313-325
Our research in the past decade has focused around delineating the functional significance of high affinity folate-binding proteins (FBP). ${ }^{1}$ We have shown that while membrane-associated and soluble FBPs are intimately interrelated (7-12), membrane-associated FBPs played an important role as folatebinding and transport proteins (receptors) in the cellular uptake of folates in human nasopharyngeal carcinoma (KB) cell lines (13). With the recognition that cell growth could be sustained using 1,000-fold lower folic acid concentrations in growth media $(14,15)$, FBPs on monkey kidney cells were subsequently shown to bind and internalize folates, and recycle to the cell surface (16-18); furthermore, FBPs can be "up"- and "down"-regulated by low and high extracellular folate concentrations, respectively (19). Conversely, at pharmacological concentrations, folate also enters cells by a process which resembles passive diffusion (20).

Earlier, we determined that the majority of FBPs on intact erythrocytes were nonfunctional $(20,21)$; however, when rabbit anti-PFR antiserum (but not nonimmune or PFR-neutralized anti-PFR antiserum) was incubated with developing erythroid progenitor cells in vitro, we observed that burst forming unit (BFU)-erythroid (E)-derived normoblasts exhibited increased cloning efficiency and had biochemical evidence of intracellular folate deficiency as well as megaloblastic morphology (22). Thus, we concluded that normal human cells also relied on folate receptors for cellular folate uptake. Since this in vitro model resembles in vivo folate deficiency, we wished to determine if anti-PFR antiserum effects (increased cloning efficiency and megaloblastic changes) were specific, independent effects, or inextricably associated with one another as either obligate simultaneous or temporally sequential events. We present data which indicate that megaloblastic changes and increased cloning efficiency as induced by anti-PFR antisera during in vitro hematopoiesis are dissociable events, although both are very likely caused by perturbation of folate receptors on hematopoietic progenitor cells.

\section{Methods}

Iscove's Modified Dulbecco's Medium (IMDM) containing $4 \mathrm{mg}$ folic acid per liter was obtained from Gibco, Grand Island, NY. Partially purified human urinary erythropoietin $(72 \mathrm{U} / \mathrm{mg}$ of protein) was from Toyobo Co., New York, NY. FBS and rabbit nonimmune serum were

1. Abbreviations used in this paper: BFU-E, burst forming units-erythroid; CFU, colony forming units; E, erythroid; FBP, folate binding proteins; GEMM, granulocyte-erythrocyte-megakaryocyte-macrophage; GM, granulocyte-macrophage; LDMNC, low-density mononuclear cells; 2-ME, 2-mercaptoethanol; PFR, placental folate receptors; PHA-LCM, phytohemagglutinin-stimulated lymphocyte conditioned medium. 
from HyClone Laboratories, Inc., Logan, UT, whereas [methyl- ${ }^{3} \mathrm{H}$ ] thymidine (sp act $20 \mathrm{Ci} / \mathrm{mmol}$, stock solution $1 \mathrm{mCi} / \mathrm{ml}$ ) and [phenyl${ }^{3} \mathrm{H}(N)$ ]-Triton X-100 (sp act $1.58 \mathrm{mCi} / \mathrm{mg}$ ) were from DuPont Co. Diagnostic and BioResearch Systems, Wilmington, DE, and New England Nuclear, Boston, MA. Sodium iodide, carrier free, $14.2 \mathrm{mCi} / \mu \mathrm{g}$ sp act of iodine was from Amersham Corp., Arlington Heights, IL. Folic acid ( $98 \%$ pure), cyanogen bromide-activated Sepharose 4B, Amberlite XAD-2, monobasic and dibasic potassium phosphate $\left(\mathrm{KPO}_{4}\right)$ were from Sigma Chemical Co., St. Louis, MO. Methylcellulose, Wright Giemsa "Accustain," Schiff's reagent and cresyl violet were from Fisher Scientific Co., Fairlawn, NJ, whereas DEAE Affi-Gel Blue was from Bio-Rad, Richmond, CA. Ficoll-Hypaque was from Pharmacia Fine Chemicals, Piscataway, NJ, whereas 2-mercaptoethanol (2ME) was from Eastman Kodak Co., Rochester, NY, and homogeneous goat anti-rabbit IgG was from Cappel Laboratories, Cochranville, PA. Phytohemagglutinin-stimulated lymphocyte conditioned medium (PHA-LCM) was prepared as described (23). Fluorescein-conjugated goat $F\left(a b^{\prime}\right)_{2}$ anti-rabbit IgG was from Meloy Laboratories, Springfield, VA. GammaBind G-Agarose (recombinant protein $G$ coupled to Sepharose 4B) was from Genex Corp., Gaithersburg, MD, and IgGsorb, a $10 \%$ suspension of formalin-fixed Staphylococcus aureus cells bearing protein A (binding capacity $=1.79 \mathrm{mg} \mathrm{IgG/ml}$ ) was from the Enzyme Center, Malden, MA

\section{Preparation of PFR and anti-PFR antiserum}

PFR was purified to apparent homogeneity and rabbit anti-PFR antiserum was raised as described (7).

\section{Purification of total IgG from crude nonimmune and anti- PFR antiserum}

(a) Goat anti-rabbit IgG coupled to cyanogen bromide-activated Sepharose (24) was reacted with crude rabbit anti-PFR antiserum, as described (25). The affinity column containing bound rabbit IgG was washed with 20 column vols of PBS $\left(10 \mathrm{mM} \mathrm{KPO}_{4}, \mathrm{pH} 7.5\right.$, containing $150 \mathrm{mM} \mathrm{NaCl}$ ) followed by batch-elution of bound IgG using 3 column vols of $0.1 \mathrm{M}$ glycine- $\mathrm{HCl}, \mathrm{pH} 2.5$, containing $1 \mathrm{M} \mathrm{NaCl}$. After raising the $\mathrm{pH}$ of the eluate to 7.5 with $1 \mathrm{~N} \mathrm{NaOH}$, the sample was subjected to $50 \%$ ammonium sulfate precipitation and dialysis followed by further purification over DEAE-cellulose, as described (25). (b) Crude rabbit sera were also subjected to $50 \%$ ammonium sulfate precipitation followed by resuspension in $3 \mathrm{ml}$ of dialysis/column buffer ( $20 \mathrm{mM}$ Tris$\mathrm{HCl}, \mathrm{pH} 8$, containing $28 \mathrm{mM} \mathrm{NaCl}$ and $0.02 \%$ sodium azide) and dialysed against 1 liter dialysis/column buffer with three changes. The samples were then applied over a $1.5 \times 30 \mathrm{~cm}$ DEAE Affi-Gel Blue column which was equilibrated and eluted with dialysis/column buffer. Fractions of $3 \mathrm{ml}$ were collected and the peak protein fractions (fractions 7-13) were pooled and filter-concentrated in an Amicon concentrator using a YM 10 membrane. The retenate was dialysed against 1 liter PBS over three changes and further purified (26) by incubation for $2 \mathrm{~h}$ with GammaBind G-Agarose in PBS. The affinity gel-bound IgG was then washed and batch-eluted with $10 \mathrm{ml}$ of $0.5 \mathrm{M}$ sodium acetate, pH 3, and the eluate was subsequently dialysed, filtered, and concentrated, as described above.

\section{Preparation of control immune sera}

Polyspecific rabbit anti-human platelet glycoprotein antiserum, which reacts with a number of platelet-related antigens extracted with lithium diiodosalicylate-phenol, was prepared as described $(27,28)$. Rabbit polyclonal monospecific anti-human glycophorin antiserum $(29,30)$ was a gift from Dr. J. T. Elder (Yale University).

\section{Immunodiffusion studies}

Crude anti-PFR antiserum $(20 \mu \mathrm{l})$ or nonimmune serum $(20 \mu \mathrm{l})$ was reacted against $10 \mu \mathrm{g}$ purified apo-PFR or $10 \mu \mathrm{g}$ purified PFR saturated with $0.25 \mu \mathrm{mol}$ unlabeled PteGlu, as described (7).
Isolation of bone marrow low-density mononuclear cells (LDMNC)

LDMNC from normal human bone marrow were prepared as previously described (22). In some experiments, LDMNC were further fractionated into a population of nonadherent LDMNC ( $>97 \%$ esterase negative), and these cells were further depleted of $\mathrm{T}$ cells ( $>97 \% \mathrm{~T}$ cell depletion), as described $(31,32)$.

Determination of the antigen(s) on LDMNC which react with anti-PFR antiserum

(a) After iodination of LDMNC surface membrane proteins. Externally-oriented proteins on $9 \times 10^{7}$ intact LDMNC were iodinated with $1 \mathrm{mCi}\left[{ }^{125} \mathrm{I}\right] \mathrm{NaI}$ and $20 \mu \mathrm{g}$ iodogen, as previously described (21). After five centrifuge-wash cycles $(1,000 \mathrm{~g}$ for $10 \mathrm{~min})$ using $50 \mathrm{ml}$ PBS per wash, cells were assessed for viability, after which membrane proteins

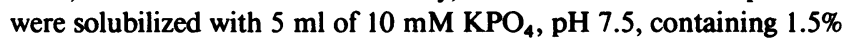
Triton X-100, $0.1 \%$ sodium azide, and $10 \mathrm{mM}$ EDTA for $24 \mathrm{~h}$ at $4^{\circ} \mathrm{C} .1$ $\mathrm{ml}$ of IgGsorb was then added and incubation continued for $2 \mathrm{~h}$. The sample was then centrifuged at $30,000 \mathrm{~g}$ for $1 \mathrm{~h}$ and the supernatant was sequentially reacted with $100 \mu \mathrm{l}$ nonimmune serum for $16 \mathrm{~h}$ and 1 $\mathrm{ml}$ IgGsorb for $2 \mathrm{~h}$, followed by $100 \mu \mathrm{l}$ crude anti-PFR antiserum for 16 $\mathrm{h}$ and $1 \mathrm{ml}$ IgGsorb for $2 \mathrm{~h}$ as described above. After washing the IgGsorb pellets four cycles with 30 vols of PBS, they were boiled in 5\% SDS for $5 \mathrm{~min}$. After centrifugation in a microfuge, the boiled supernatants were subjected to $15 \%$ SDS-PAGE and autoradiography, as described (21). A similar experiment where GammaBind G-agarose-purified IgG $(120 \mu \mathrm{g})$ from nonimmune serum and anti-PFR antiserum were substituted for crude sera was also carried out.

(b) After isolation of particulate membranes of LDMNC and iodination of solubilized-particulate proteins. Bone marrow LDMNC (4 $\times 10^{8}$ cells) harvested from four different subjects over $2 \mathrm{wk}$ and stored at $-20^{\circ} \mathrm{C}$ were thawed and pooled; none of the cells were viable. After centrifugation at $1,000 \mathrm{~g}$ for $10 \mathrm{~min}$ at $4^{\circ} \mathrm{C}$, the supernatants were centrifuged at $100,000 \mathrm{~g}$ for $1 \mathrm{~h}$ in a model L8-55M ultracentrifuge (Beckman Instruments, Inc., Fullerton, CA) using a 70 Ti rotor. The membrane pellets were resuspended in 50 vols of $10 \mathrm{mM} \mathrm{KPO}_{4}, \mathrm{pH}$ 7.5 , washed twice, as described above, and solubilized in $8 \mathrm{ml}$ of PBS containing $1.5 \%$ Triton X-100, $20 \mathrm{mM}$ EDTA and $0.1 \%$ sodium azide for $16 \mathrm{~h}$ at $4^{\circ} \mathrm{C}$. After centrifugation at $100,000 \mathrm{~g}$ for $1 \mathrm{~h}$, the supernatant was aspirated and dialysed against 4 liters of $10 \mathrm{mM} \mathrm{KPO}_{4}, \mathrm{pH}$ 7.5 , containing $1 \%$ Amberlite XAD-2, with dialysate changes every 12 $\mathrm{h}$ for four changes. The dialysed sample was evaporated in a Savant Speed-vac centrifuge and $200 \mu \mathrm{l}$ of $\mathrm{H}_{2} \mathrm{O}$ and $6 \times 10^{6} \mathrm{cpm}$ of [phenyl${ }^{3} \mathrm{H}(\mathrm{N})$ ]-Triton X-100 was added as a marker to determine the efficiency of subsequent Triton X-100 removal with diethyl ether (8). The efficiency of detritonization was $>95 \%$ after eight cycles based on the residual amount of radioactivity in the sample. After drying, the sample was resuspended in $1 \mathrm{ml}$ of $\mathrm{H}_{2} \mathrm{O}$ and iodinated (21) with $100 \mu \mathrm{g}$ iodogen and $1 \mathrm{mCi}$ [ $\left.{ }^{125} \mathrm{I}\right] \mathrm{NaI}$ for $20 \mathrm{~min}$ at $22^{\circ} \mathrm{C}$. After quenching the reaction mixture with $0.1 \mathrm{M}$ unlabeled $\mathrm{NaI}$, the sample was resuspended in $1 \%$ Triton X-100 and applied to a calibrated $1 \times 30 \mathrm{~cm}$ Sephadex G-25 column which was equilibrated and eluted with $10 \mathrm{mM}$ $\mathrm{KPO}_{4}, \mathrm{pH} 7.5$, containing $1 \%$ Triton X-100. Fractions of $2.75 \mathrm{ml}$ were collected and the void volume plus one fraction preceeding it and two subsequent fractions containing the maximum radioactivity were pooled. The pooled fractions were sequentially reacted with $120 \mu \mathrm{g}$ each of GammaBind G-Agarose-purified IgG from rabbit nonimmune serum and anti-PFR antiserum, and analyzed by $15 \%$ SDS-PAGE and autoradiography, as described above.

\section{Hematopoietic progenitor cell assays}

Assays for the cloning efficiency of BFU-E-, CFU-E-, CFU-GM-, and CFU-GEMM-derived colonies were carried out according to the method of Fauser and Messner (33). In brief, $\sim 1 \times 10^{5}$ LDMNC were suspended in $35 \mathrm{~mm}$ standard tissue culture dishes, containing a 1-ml mixture of IMDM, $1.1 \%$ methylcellulose, $30 \%$ FBS, $10 \%$ PHA-LCM, 5 $\times 10^{-5} \mathrm{M} 2-\mathrm{ME}, 1$ unit of erythropoietin, and $10 \%$ of either $(a)$ rabbit 
nonimmune (control) serum, $(b)$ rabbit anti-human PFR antiserum, (c) PFR-neutralized anti-PFR antiserum, (d) $120 \mu \mathrm{g}$ of purified IgG from nonimmune or anti-PFR antiserum diluted in $100 \mu \mathrm{l}$ PBS, $(e)$ rabbit anti-glycophorin antiserum, or $(f)$ anti-platelet glycoprotein antiserum. For dose-response studies, nonimmune serum or anti-PFR antiserum was diluted at various concentrations in a final volume of $100 \mu \mathrm{l}$ of PBS. To prepare PFR-neutralized anti-PFR antiserum, $800 \mu \mathrm{l}$ anti-PFR antiserum was incubated with $2 \mu \mathrm{g}$ purified human PFR

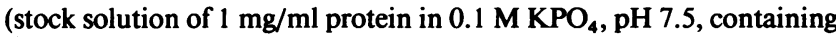
$1 \%$ Triton $\mathrm{X}-100$ ) for $2 \mathrm{~h}$ at $37^{\circ} \mathrm{C}$. The culture plates were incubated at $37^{\circ} \mathrm{C}$ in a light-protected, $100 \%$ humidified atmosphere of $5 \% \mathrm{CO}_{2}$ in air. Erythroid colonies (CFU-E- and BFU-E-derived) were scored after 7 and $14 \mathrm{~d}$, respectively, using standard morphologic criteria, whereas established criteria were used for the recognition and scoring of CFUGM- and CFU-GEMM-derived colonies (33).

\section{Cellular interaction with anti-PFR antiserum and the proliferative response}

(a) We determined if the proliferative response that followed anti-PFR antiserum interaction with folate receptors on LDMNC was lost as a function of lengthening the duration between isolation of these cells and subsequent incubation with antisera. This was accomplished by progressively increasing the duration between isolation of LDMNC (incubated at $4^{\circ} \mathrm{C}$ in IMDM containing $10 \%$ FBS) and their subsequent long-term incubation with various sera in the standard hematopoietic assays. Cell viability studies by Trypan Blue exclusion were performed on LDMNC immediately before plating. Megaloblastosis of BFU-Ederived normoblasts was also determined (see below).

(b) To determine if anti-PFR antiserum-induced megaloblastic changes were invariably associated with, and/or essential for the observed increased cloning efficiency, the influence of the duration of contact of anti-PFR antiserum with LDMNC (before plating) was subsequently evaluated. Briefly, LDMNC $\left(1 \times 10^{6}\right)$ were incubated at time-zero at $4^{\circ} \mathrm{C}$ with $10 \%$ anti-PFR antiserum, nonimmune serum, or PFR-neutralized antiserum, and 30\% FBS in a final volume of $10 \mathrm{ml}$ IMDM. At various later times, $0.2-\mathrm{ml}$ aliquots of cell suspension were resuspended into $4.8 \mathrm{ml}$ IMDM and subjected to two centrifuge wash cycles $\left(10 \mathrm{~min}\right.$ at $400 \mathrm{~g}$ at $4^{\circ} \mathrm{C}$ ), to ensure removal of sera. The pellet of cells was resuspended in $0.4 \mathrm{ml}$ IMDM and subsequently plated in the culture, as described above.

(c) Subsequent experiments were constructed to determine if the anti-PFR antiserum-induced proliferative response could be quenched under conditions where the megaloblastic changes could be abrogated by preventing intracellular folate deficiency, as recently described (20). Based on folate determination (34) and the known value of folic acid in IMDM, the concentration of folic acid in the incubation mixture during in vitro hematopoiesis was $5.5 \mu \mathrm{M}$. In addition to routine cultures, experiments with anti-PFR antiserum and nonimmune serum incubated with LDMNC in the presence of $2.8 \mathrm{mM}$ folic acid were also constructed, and the number of CFU-E- and BFU-E-derived colonies per plate and morphology of orthochromatic normoblasts were subjectively and objectively (quantitatively) determined, as described $(20,22)$.

(d) To determine if the rapid proliferative response of hematopoietic progenitor cells after contact with anti-PFR antiserum was mediated only by a single cohort of cells in S-phase of the cell-cycle, LDMNC (which were incubated with anti-PFR antiserum or nonimmune serum for various times) were briefly exposed to [methyl- ${ }^{3} \mathrm{H}$ ] thymidine followed by a chase with excess unlabeled thymidine; after washing away excess radioactive thymidine, the cells were plated. Briefly, $8.33 \mathrm{ml}\left(1 \times 10^{6}\right.$ cells $\left./ \mathrm{ml}\right)$ LDMNC were incubated with 31.67 $\mathrm{ml}$ IMDM, $5 \mathrm{ml}$ nonimmune serum or anti-PFR antiserum, and $5 \mathrm{ml}$ FBS at $4^{\circ} \mathrm{C}$. At various times, $1-\mathrm{ml}$ aliquots of cell suspension were centrifuged at $400 \mathrm{~g}$ for $10 \mathrm{~min}$ at $4^{\circ} \mathrm{C}$ and the supernatant was aspirated. IMDM, $0.5 \mathrm{ml}$, containing $10 \% \mathrm{FBS}$ and $50 \mu \mathrm{Ci}$ [methyl- ${ }^{3} \mathrm{H}$ ] thymidine, was then added to the cell pellet and the mixture was incubated for $20 \mathrm{~min}$ at $37^{\circ} \mathrm{C}$ in a $100 \%$ humidified atmosphere of $5 \% \mathrm{CO}_{2}$ in air. Unlabeled thymidine, $0.5 \mathrm{ml}$ (stock solution $5 \mathrm{mg} / \mathrm{ml}$ in IMDM), and $2 \mathrm{ml}$ IMDM, was then added to the mixture of cells and incubation at $37^{\circ} \mathrm{C}$ was carried out for another $20 \mathrm{~min}$. After adding 2 $\mathrm{ml} \mathrm{IMDM}$, the sample was centrifuged at $400 \mathrm{~g}$ for $10 \mathrm{~min}$ at $4^{\circ} \mathrm{C}$, and the supernatant was aspirated. This centrifuge-wash cycle using $2 \mathrm{ml}$ IMDM was repeated twice to remove radioactive thymidine that was not incorporated into cells during the initial incubation $(20 \mathrm{~min}$ at $37^{\circ} \mathrm{C}$ ). The washed cell pellet was then resuspended in $0.3 \mathrm{ml}$ IMDM and added to the standard culture for hematopoietic progenitor cells, as described above. Duplicate samples which were not exposed to [methyl- ${ }^{3} \mathrm{H}$ ] thymidine, but exposed to all other experimental variables described above, were also carried out.

\section{Morphology and cytophotometry of normoblasts composing CFU-E-derived colonies}

Erythroid colonies developed in anti-PFR antiserum or nonimmune serum were plucked, cytocentrifuged onto glass slides and either $(a)$ air-dried and stained with Wright-Giemsa "Accustain" (which contains a fixative) and observed for morphological changes, as described (20), (elimination of the additional glutaraldehyde cell-fixation step before staining [22] resulted in less shrinkage of cells without compromising fine details of morphology), or (b) fixed with methanol:formalin:glacial acetic acid (85:10:5) before cytophotometry. Duplicate preparations were stained for DNA or RNA. The Feulgen reaction for staining DNA consisted of hydrolysis in $5 \mathrm{~N} \mathrm{HCl}$ at $25^{\circ} \mathrm{C}$ for $60 \mathrm{~min}$, and 60 min in Schiff's reagent ( $\mathrm{pH} 1.5$, adjusted before use). Cells were stained for RNA with cresyl violet $(0.1 \%, \mathrm{pH} 4.2)$ for $2 \mathrm{~h}$ at $45^{\circ} \mathrm{C}$, followed by extraction with $100 \%$ ethanol for $16 \mathrm{~h}$. All slides were mounted in histoclad and cytophotometry with a Leitz Orthoplan microscope with scanning stage and MPV photometer (E. Leitz, Inc., Rockleigh, NJ) was used to quantitate DNA and RNA in individual erythroid precursors $(35,36)$. Cells were scanned at $0.6-\mu \mathrm{m}$ intervals $(0.6 \times 0.6 \mu \mathrm{m}$ measuring spot) under oil immersion $(1,250 \times)$ at selected wavelength ( $560 \mathrm{~nm}$ for DNA, $580 \mathrm{~nm}$ for RNA) using interference filters $( \pm 5 \mathrm{~nm}$ bandwidth). Total amount of DNA or RNA was based on the total integrated optical density at the appropriate wavelength $(35,36)$. Segmented polymorphonuclear neutrophil nuclei were measured as the $2 \mathrm{~N}$ reference cells (coefficient of variation $<5 \%$ ) for calculating ploidy classes (35).

\section{Immunofluorescence analysis}

(a) Using crude sera. Washed LDMNC $\left(1 \times 10^{5}\right)$ were incubated with $10 \mu \mathrm{l}$ of either crude rabbit anti-PFR antiserum, nonimmune serum or PFR-neutralized anti-PFR antiserum in $1 \mathrm{ml}$ of IMDM for $2 \mathrm{~h}$ at $4^{\circ} \mathrm{C}$. After three centrifuge-wash cycles with 20 vol PBS, the cells were incubated with 1:200 dilution of fluorescein isothiocyanate (FITC)-labeled goat $\mathrm{F}\left(\mathrm{ab}^{\prime}\right)_{2}$ anti-rabbit IgG for $2 \mathrm{~h}$ at $4^{\circ} \mathrm{C}$. After three centrifuge-wash cycles, as described above, the cells were transferred onto glass slides and observed under fluorescent light, as described (7).

(b) Using GammaBind G-agarose-purified IgG. LDMNC (1 $\times 10^{6}$ ) were incubated with $20 \mu \mathrm{g}$ of either nonimmune IgG or antiPFR IgG for $20 \mathrm{~min}$ at $4^{\circ} \mathrm{C}$, washed with ice-cold $5 \mathrm{ml} \mathrm{PBS}$ and incubated with $4 \mu \mathrm{g}$ FITC-conjugated swine anti-rabbit immunoglobulins (Dakopatts, Denmark) for another $20 \mathrm{~min}$ at $4^{\circ} \mathrm{C}$. After washing with PBS, the cells were fixed by suspension in $1 \%$ paraffin formaldehyde and analyzed by fluorescence activated cell sorting, as described (37).

\section{Other methods}

Protein concentrations were determined by the method of Lowry et al. (38). Folate concentrations in rabbit nonimmune and anti-PFR antiserum were determined as described (21). The concentration of PteGlu was determined from extinction coefficients given by Blakley (39).

\section{Statistical analyses}

(a) Analysis of the data on cloning efficiency of LDMNC, nonadherent LDMNC, and nonadherent T cell-depleted LDMNC from a single individual performed in four replicates in the presence of either IMDM 
(no addition), nonimmune serum, or anti-PFR antiserum was carried out for CFU-E-, BFU-E, CFU-GM- and CFU-GEMM-derived colonies using standard analysis of variance (ANOVA) techniques (40). Because these data were measured counts, the square root transformation was applied to the observed responses to stabilize the variance of the mean response, and thus satisfy the assumptions that underlie ANOVA techniques (41). (b) Data for the cloning efficiency of CFU-E-, BFU-E-, CFU-GM-, and CFU-GEMM-derived colonies from LDMNC from different human subjects were obtained by taking at least two cultures on the same human subject under differing experimental conditions (e.g., exposure to antiserum, nonimmune serum, etc.), and repeating this procedure for different human subjects. Consequently, statistical comparisons between the number of colonies derived under two different study conditions (e.g., nonimmune serum versus "no addition") were carried out using weighted repeated measures analysis of variance (ANOVA) on the mean response measured for each human subject under each specific condition. The weights employed in the calculations consisted of the inverse of the variance calculated for the mean of each subject. When all weights are the same, and the comparison of two conditions is of interest, this methodology is equivalent to using a paired $t$ test (40). Identical analyses were used for data obtained on CFU-E-, BFU-E-, CFU-GM-, and CFU-GEMM-derived colonies. All statistical tests were carried out using the significance level $\alpha=0.05$. (c) For cytophotometric studies, differences in mean total DNA, RNA, and nuclear area were analyzed using Student's $t$ test, whereas ploidy profiles were compared using Pearson's chi-square. $(d)$ One-way ANOVA was utilized to compare normoblast diameters obtained from BFU-E-derived colonies (exposed to the different experimental conditions resulting in Table V), whereas comparisons of the number of normoblasts having greater than one nucleus under these different conditions were accomplished using Pearson's chi-square tests. Potential differences in cloning efficiency observed for CFU-E- and BFU-E-derived colonies under the different experimental conditions were investigated using one-way ANOVA on the square root of the observed counts. The Student-Newman-Keuls multiple comparison procedure was used in conjunction with the one-way ANOVA to control the experimentwise error rate at the $\alpha=0.05$ level (40). To control the experimentwise error rate of the multiple chi-square tests that were performed, the Bonferroni procedure of Hochberg (42) was applied to the $P$ values obtained from these tests.

\section{Results}

Characterization of the specificity of anti-PFR antiserum. We have previously provided detailed evidence to support the conclusion that the antigen used to generate anti-PFR antiserum was apparently homogeneous $(7,11,21)$. On immunodiffusion studies, the reaction between antiserum and apo- or holo-PFR wells revealed single precipitin lines of identity (Fig. $1 \mathrm{~A}$ ); nonimmune serum, on the other hand, did not react with PFR (Fig. $1 B$ ). Using FITC-labeled goat $\mathrm{F}\left(\mathrm{ab}^{\prime}\right)_{2}$ anti-rabbit IgG as a probe to detect the presence of rabbit IgG molecules on the surface of LDMNC suspended in IMDM containing $9 \mu \mathrm{M}$ folic acid, we observed that only those cells exposed to anti-PFR antiserum exhibited surface fluorescence; furthermore, when antiserum was neutralized by preincubation with purified PFR, there was complete quenching of fluorescence suggesting that the anti-PFR antiserum was specific for folate receptors on these cells (data not shown). This possibility was further strengthened when apparently homogeneous (GammaBind G-agarose-purified) IgG isolated from anti-PFR antiserum and nonimmune serum was employed for immunofluorescence analysis by cell sorting. Fig. 2 shows that immune (antiPFR) IgG reacted with LDMNC to produced a significant (approximately fivefold) increase in immunofluorescence inten-

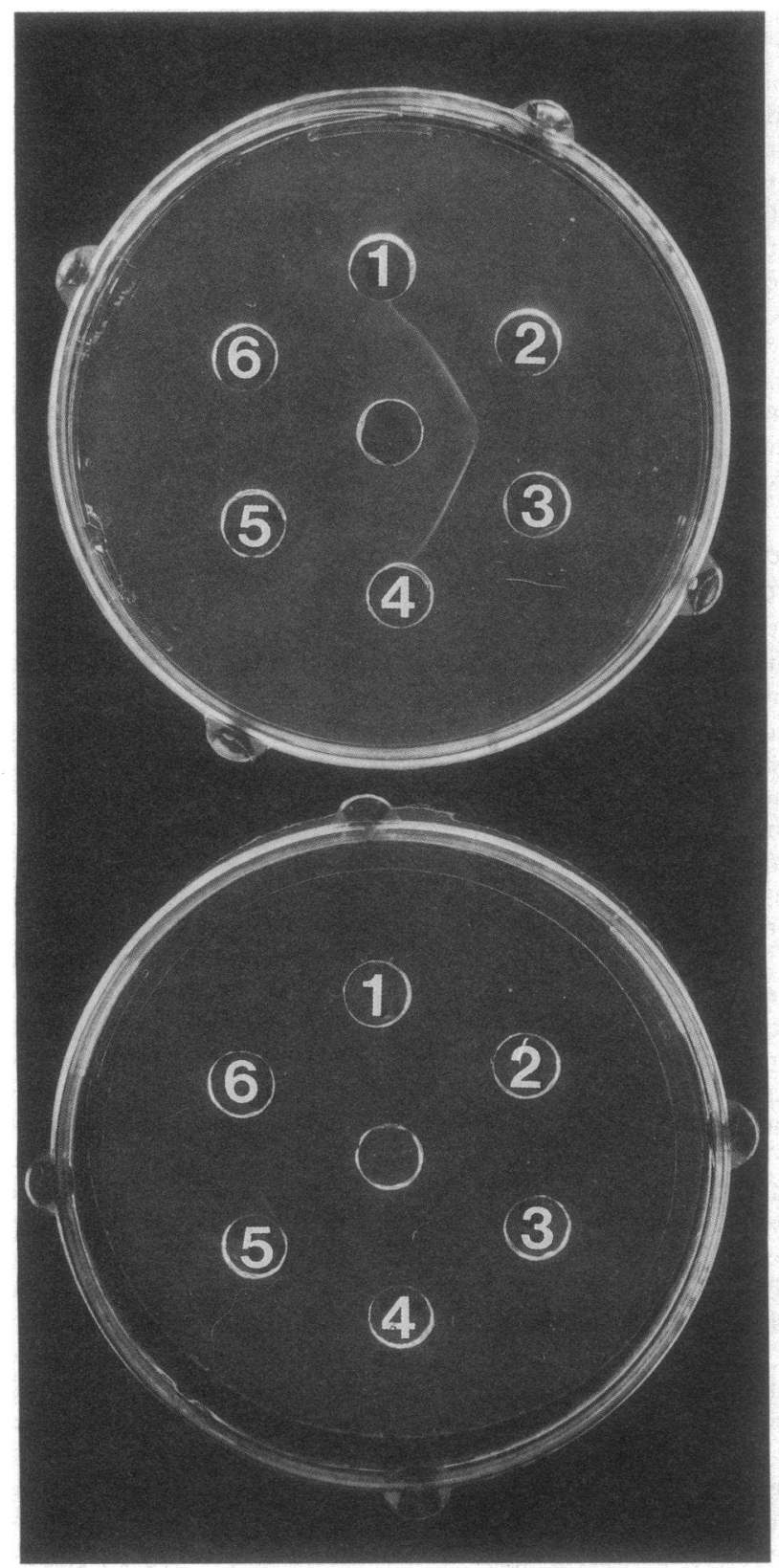

Figure 1. Immunodiffusion studies. (Top disc) Center well, $20 \mu \mathrm{l}$ purified anti-PFR antiserum; well $2,10 \mu \mathrm{g}$ purified apo-PFR; well 3 , $10 \mu \mathrm{g}$ purified holo-PFR. (Bottom disc) Center well, $20 \mu \mathrm{l}$ nonimmune serum; well $2,10 \mu \mathrm{g}$ purified apo-PFR; well $3,10 \mu \mathrm{g}$ purified holoPFR. The remaining wells in both discs contained equilibration buffer.

sity when compared to equal concentrations of nonimmune IgG. However, xenogenic polyclonal antiserum to a purified glycoprotein can frequently react with additional distinct glycoproteins which share similar carbohydrate structural features. To be certain that anti-PFR antiserum did not react with more than one species of cell surface proteins, we iodinated LDMNC (98\% viability, > 90\% purity) and specifically immunoprecipitated iodinated species with crude anti-PFR antisera. When $9 \times 10^{7}$ LDMNC were surface iodinated, solubilized, and sequentially reacted with IgGsorb, nonimmune serum and IgGsorb, followed by anti-PFR antiserum and IgGsorb, a single unique species of immunoprecipitated iodinated 


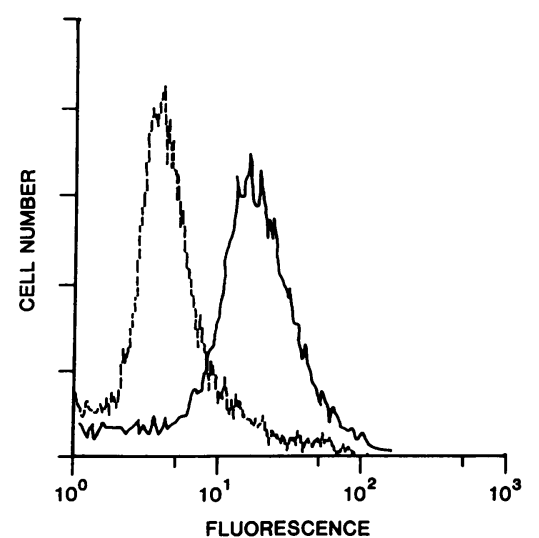

material migrating at $44 \mathrm{kD}$ was identified on subsequent SDSPAGE and autoradiography (Fig. 3, left, lane 3). The additional bands (in lane 3 ) including one corresponding to the $M_{\mathrm{r}}$ of aglycofolate receptors at $\sim 27 \mathrm{kD}(7,43)$ were also identified in nonimmune serum-treated supernatant (Fig. 3, left, lane 2) on prolonged autoradiography. These additional bands were not observed when similar experiments were carried out with apparently homogeneous IgG from nonimmune and anti-PFR antiserum which again specifically immunoprecipitated only the 44-kD species (not shown); thus the additional bands were likely related to the crude sera used. The $44-\mathrm{kD}$ species was of comparable $M_{\mathrm{r}}$ to purified solubilized particulate folate receptors present on other human cells $(7-13,15)$. This approach, however, does not rule out the possibility that anti-PFR IgG immunoprecipitated another distinct protein on the surface of LDMNC which failed to be iodinated while in its native state on LDMNC. Particulate membrane proteins from LDMNC (4 $\times 10^{8}$ cells) were therefore solubilized, detritonized, iodinated, and sequentially reacted with IgGsorb, purified nonimmune IgG followed by IgGsorb, and finally by purified anti-PFR IgG. After immunoprecipitating the ${ }^{125} \mathrm{I}$-antigen-anti-PFR IgG complexes with IgGsorb followed by SDS-PAGE and autoradiography, the data (Fig. 3, right, lane $B$ ) still revealed a single species. Thus, despite the use of a technique (specific immunoprecipitation) that allowed us to assess a significantly greater number of cells than possible with conventional immunoblotting techniques, we could not demonstrate that anti-PFR IgG reacted with any additional membrane proteins on LDMNC.

Effect of anti-PFR antiserum on cloning efficiency. In preliminary studies we noted that different human subjects' LDMNC exhibited different baseline levels of cloning effciency (with nonimmune serum). However, in the presence of anti-PFR antiserum, there was a dose-dependent increase in cloning efficiency relative to growth in nonimmune serum (data not shown). Although the actual data points in the doseresponse curves suggested a distinct trend of increased cloning efficiency with increased dose of anti-PFR antiserum in a single subject, the wide degree of variation at the lower dose levels with antiserum precluded meaningful comparisons among the cell responses from various subjects. Therefore, we examined the cloning efficiency at $100 \mu \mathrm{l}$ anti-PFR antiserum because cells from all subjects consistently exhibited increased cloning efficiency $(<10 \%$ variation from the mean for each subject's
LDMNC) at this level. The weighted mean number of progenitor cell-derived colonies $/ 10^{5}$ LDMNC plated, the standard errors of these means, and the number of human subjects used in calculating the means for CFU-E-, BFU-E-, CFU-GM-, and CFU-GEMM-derived colonies are presented in Table I A. The data suggest that when anti-PFR antiserum (but not nonimmune serum) was incubated with LDMNC, there was increased cloning efficiency of CFU-E-, BFU-E-, CFU-GM-, and CFU-GEMM-derived colonies. Five statistical comparisons were performed on the weighted means obtained for CFU-Eand BFU-E-derived colonies, whereas only two were performed for CFU-GM- and CFU-GEMM-derived colonies. These comparisons, along with their corresponding $P$ values and number of paired observations are presented in Table I B. The results indicated a highly significant difference in the number of progenitor cell-derived colonies under the anti-PFR antiserum experimental condition as compared to the nonimmune serum condition for CFU-E-, BFU-E-, and CFU-GMderived colonies $(P<0.005)$; however, the results for the test applied to the CFU-GEMM-derived colonies only approached statistical significance $(P=0.065)$. For CFU-E-derived colonies, there was also a highly significant difference between antiPFR antiserum and anti-PFR antiserum + PFR $(P<0.001)$. The comparison of BFU-E-derived colonies under the antiPFR antiserum and anti-PFR antiserum + PFR [neutralized

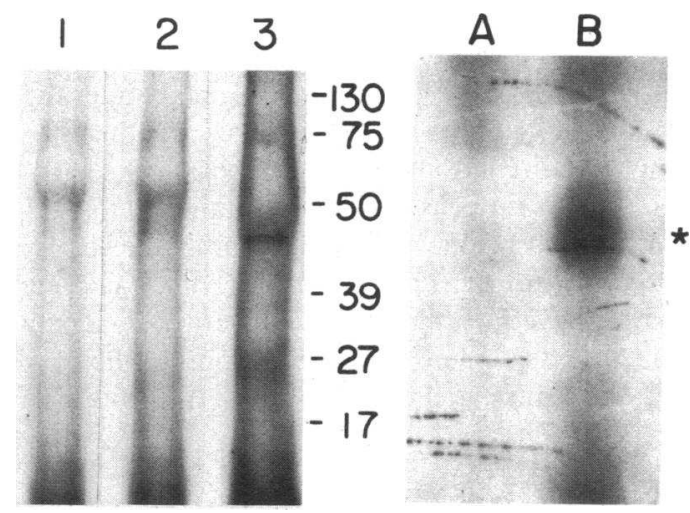

Figure 3. Immunoprecipitation of cell surface-iodinated LDMNC proteins and iodinated total solubilized-membrane proteins from LDMNC. (Left) Membrane proteins on the surface of $9 \times 10^{7}$ LDMNC were iodinated, solubilized with $1.5 \%$ Triton X-100 and the sample was sequentially treated with IgGsorb (lane 1 ), crude rabbit nonimmune serum followed by IgGsorb (lane 2 ), and finally by crude anti-PFR antiserum followed by IgGsorb (lane 3) as described in Methods. The washed IgGsorb pellets were boiled in SDS containing 2-ME, centrifuged, and the supernatant containing released iodinated material was run on $15 \%$ SDS-PAGE and the gels were autoradiographed to identify nonspecifically precipitated (lanes $l$ and 2) and specifically immunoprecipitated radioactivity (lane 3). The relative migration of known molecular weight marker proteins (in kilodaltons) is shown on the right, and the gel was run from top to bottom. (Right) Particulate membrane proteins from $0.4 \times 10^{9}$ cells were solubilized, detritonized, iodinated, and chromatographed as described in Methods. After reaction with IgGsorb, the sample was sequentially reacted with $120 \mu \mathrm{g}$ each of GammaBind G-agarosepurified IgG from rabbit nonimmune and IgGsorb (lane $A$ ) and then with anti-PFR antiserum and IgGsorb (lane $B$ ) and analyzed by $15 \%$ SDS-PAGE as described above. The gel was run from top to bottom and the asterisk identifies the single species immunoprecipitated with anti-PFR IgG. 
Table IA. Weighted Means, Standard Deviations, and Number of Subjects Tested for Cloning Efficiency of CFU-E-, BFU-E-, $C F U-G M-$, and CFU-GEMM-derived Colonies under Various Experimental Conditions

\begin{tabular}{|c|c|c|c|c|}
\hline \multirow{2}{*}{$\begin{array}{l}\text { Experimental } \\
\text { condition }\end{array}$} & \multicolumn{4}{|c|}{ Cloning efficiency per $1 \times 10^{5}$ cells plated } \\
\hline & CFU-E & BFU-E & CFU-GEMM & CFU-GM \\
\hline $\begin{array}{l}\text { Nonimmune } \\
\text { serum }\end{array}$ & $\begin{array}{l}56.4 \pm 1.37 \\
(13)\end{array}$ & $\begin{array}{c}44.2 \pm 1.08 \\
(13)\end{array}$ & $\begin{array}{c}6.5 \pm 1.20 \\
(6)\end{array}$ & $\begin{array}{l}53.6 \pm 1.08 \\
(6)\end{array}$ \\
\hline $\begin{array}{l}\text { Nonimmune } \\
\text { serum } \\
+ \text { PFR }\end{array}$ & $46.5 \pm 0.91$ & $34.5 \pm 1.01$ & - & - \\
\hline No addition & $\begin{array}{l}67.6 \pm 1.12 \\
(13)\end{array}$ & $\begin{array}{c}54.6 \pm 1.11 \\
(10)\end{array}$ & $\begin{array}{c}12.4 \pm 0.95 \\
(3)\end{array}$ & $\begin{array}{c}64.6 \pm 1.14 \\
(5)\end{array}$ \\
\hline $\begin{array}{l}\text { Anti-PFR } \\
\text { antiserum }\end{array}$ & $\begin{array}{l}126.1 \pm 1.30 \\
\quad(13)\end{array}$ & $\begin{array}{c}92.8 \pm 0.87 \\
(12)\end{array}$ & $\begin{array}{c}13.3 \pm 1.32 \\
(6)\end{array}$ & $\begin{array}{c}107.3 \pm 1.35 \\
(6)\end{array}$ \\
\hline $\begin{array}{l}\text { Anti-PFR } \\
\text { antiserum } \\
+ \text { PFR }\end{array}$ & $\begin{array}{c}46.0 \pm 0.93 \\
(6)\end{array}$ & $\begin{array}{c}43.8 \pm 1.05 \\
\quad(5)\end{array}$ & - & - \\
\hline
\end{tabular}

No. of subjects is shown in parentheses.

anti-PFR antiserum] experimental conditions yielded a marginally significant result $(P=0.059)$. All other comparisons listed within the table were nonsignificant at the 0.05 level. (Because of the small number of human subjects used in some of these comparisons, these tests only have adequate power to detect large differences between the means obtained under the different study conditions). We also determined whether two well-defined polyclonal rabbit antisera with specificity for hematopoietic cell surface antigens which were unrelated to PFR (anti-glycophorin monospecific antisera and anti-platelet glycoprotein polyspecific antisera) had similar effects on cloning efficiency as that observed with anti-PFR antiserum. The data (shown in Table V) indicated no increase in cloning efficiency with either of the two unrelated crude antisera. In addition to the anti-PFR antiserum-induced increase in cloning efficiency, we also noted a greater number of cells per colony (approximately twofold) when all hematopoietic progenitor cellderived colonies studied were incubated with anti-PFR antiserum (data not shown).

We also determined if the observed increased cloning efficiency of CFU-E-, BFU-E-, CFU-GM-, and CFU-GEMM-derived colonies with crude rabbit anti-PFR antiserum was also noted with purified IgG preparations. IgG was purified from nonimmune and anti-PFR antiserum using (a) DEAE Affi-Gel Blue, $(b)$ GammaBind G-agarose, and (c) goat anti-rabbit IgGSepharose; (the latter two methods yielded an apparently homogeneous preparation of IgG based on SDS-PAGE). Due to the expected greater concentration of IgG in antisera compared to nonimmune serum, equivalent quantities of $\operatorname{IgG}(120 \mu \mathrm{g})$ were tested and the effects on cloning efficiency of hematopoietic progenitor cell-derived colonies was determined. The results shown in Table II (representative of studies done on three normal individuals' LDMNC) indicate that the anti-PFR antiserum-derived IgG consistently led to increased cloning efficiency of CFU-E-, BFU-E-, CFU-GM-, and CFU-GEMMderived colonies when compared to IgG purified from nonimmune serum; moreover, the fold increase (data in parentheses in Table II) in cloning efficiency with highly purified (experiment 2) and apparently homogeneous (experiments 3 and 4) preparations of anti-PFR IgG was comparable to that observed with crude anti-PFR antiserum. Thus, the increased clonogenic effects of immune serum on hematopoietic progenitor cells were directly attributed to anti-PFR IgG.

To determine the effects of macrophages and $T$ cells within LDMNC in modulating antiserum-induced responses (on cloning efficiency), similar studies were carried out using nonadherent LDMNC and nonadherent T cell-depleted LDMNC. Table III contains the means and standard deviations of the four replicates that were collected under each combination of study conditions. Each replicate represents one observation from a single individual's LDMNC which were subfractionated into nonadherent LDMNC and nonadherent $\mathrm{T}$ cell-depleted

Table IB. Statistical Comparisons for Cloning Efficiency of CFU-E-, BFU-E-, CFU-GM-, and CFU-GEMM-derived Colonies Based on Data Shown in Table IA

Cloning efficiency of CFU-E- and BFU-E-derived colonies

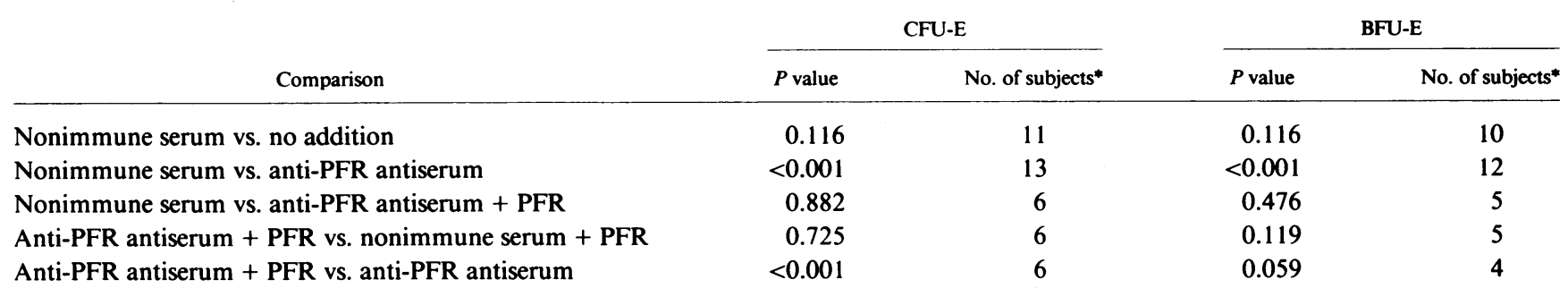

Cloning efficiency of CFU-GM- and CFU-GEMM-derived colonies

\begin{tabular}{|c|c|c|c|c|}
\hline \multirow[b]{2}{*}{ Comparison } & \multicolumn{2}{|c|}{ CFU-GM } & \multicolumn{2}{|c|}{ CFU-GEMM } \\
\hline & $P$ value & No. of subjects* & $P$ value & No. of subjects* \\
\hline Nonimmune serum vs. no addition & 0.365 & 3 & 0.165 & 3 \\
\hline Nonimmune serum vs. anti-PFR antiserum & $<0.005$ & 6 & 0.065 & 6 \\
\hline
\end{tabular}

\footnotetext{
* Reports the number of normal human subjects observed under the two conditions being compared.
} 
Table II. Representative Study of Effect of Crude and Purified IgG from Nonimmune and Anti-PFR Antiserum on Cloning Efficiency of CFU-E-, BFU-E-, CFU-GM-, and CFU-GEMM-derived Colonies

\begin{tabular}{|c|c|c|c|c|c|}
\hline \multirow[b]{2}{*}{ Experimental condition } & \multicolumn{5}{|c|}{ Cloning efficiency per $1 \times 10^{5}$ LDMNC plated } \\
\hline & CFU-E & BFU-E & CFU-GM & CFU & -GEMM \\
\hline \multicolumn{6}{|l|}{ Crude preparation IgG } \\
\hline Nonimmune serum & 100.5 & 28.0 & 27.0 & 2.0 & $(28)$ \\
\hline Anti-PFR antiserum & $184.5^{(1.8)^{+}}$ & $51.5^{(1.8)}$ & $63.5^{(2.4)}$ & 5.5 & (2.8) \\
\hline \multicolumn{6}{|l|}{ DEAE Affi-Gel Blue-purified IgG } \\
\hline Nonimmune serum & 101.5 & 27.0 & $26.5(2.0)$ & 3.0 & $(2.0)$ \\
\hline Anti-PFR antiserum & $161.5^{(1.0)}$ & $44.5^{(1.7)}$ & $53.5^{(2.0)}$ & 6.0 & \\
\hline \multicolumn{6}{|c|}{ GammaBind G-agarose-purified IgG* } \\
\hline Nonimmune serum & 110.5 & 32.5 & 27.0 & 2.0 & \\
\hline Anti-PFR antiserum & $174.5^{(1.6)}$ & $49.5^{(1.5)}$ & $56.0^{(2.1)}$ & 5.0 & $(2.5)$ \\
\hline \multicolumn{6}{|c|}{ Goat anti-rabbit IgG-Sepharose-purified IgG* } \\
\hline Anti-PFR antiserum & $171 \quad(1.6)^{8}$ & $51.5(1.6)^{8}$ & $52(1.9)^{5}$ & 6.5 & $(3.3)^{8}$ \\
\hline
\end{tabular}

Each value represents the mean of duplicate samples. Routinely, there was $<10 \%$ deviation from the mean in duplicates from a single individual with each variable. ${ }^{*}$ These preparations were apparently homogeneous based on SDS-PAGE. ${ }^{\ddagger}$ All values in parentheses represent the fold increase in cloning efficiency with IgG from antiserum compared to IgG from nonimmune serum. purified from nonimmune serum using GammaBind G-agarose.

LDMNC. Results from the two-way analysis of variance with interaction term, applied to these data for each of the CFU-E, BFU-E, CFU-GM, and CFU-GEMM experimental groups, indicated that both the overall effect due to the variable representing the three experimental conditions ("no addition," "nonimmune serum," and "anti-PFR antiserum"), and the effect representing the three cell population types were highly significant for all experimental groups $(P<0.001)$. Furthermore, contrasts applied to the parameter estimates indicated a significantly greater $(P<0.002)$ cloning efficiency for anti-PFR antiserum-treated cells as compared to nonimmune serum cells for all cell populations (LDMNC, nonadherent LDMNC, nonadherent $\mathrm{T}$ cell-depleted LDMNC) in all experimental groups (CFU-E, BFU-E, CFU-GM, CFU-GEMM). The only exception to this finding was within the CFU-GEMM-derived colonies for the nonadherent $T$ cell-depleted LDMNC population $(P=0.11)$. Overall, these results indicated that the effects of anti-PFR antibodies generally appear to be independent of the presence of macrophages and T cells in LDMNC.
Quantitation of megaloblastic changes with DNA:RNA ratios in CFU-E-derived colonies. Whereas we have correlated subjective and objective (morphometric) megaloblastic changes with biochemical changes of intracellular folate deficiency in BFU-E-derived colonies during in vitro erythropoiesis (22), others have correlated subjective evaluation of megaloblastic changes with increased DNA:RNA ratios in cells from patients with documented folate or cobalamin deficiency $(5$, 44). Therefore, it remained to be shown that the objective morphometric parameters we used to document megaloblastic changes in cells obtained during in vitro erythropoiesis were also correlated with increased DNA:RNA ratios. Because CFU-E-derived colonies (in contrast to BFU-E-derived colonies) are not known to develop megaloblastic changes during in vitro erythropoiesis (45), we determined DNA:RNA ratios in normoblasts composing CFU-E-derived colonies assayed in the presence of anti-PFR antiserum and nonimmune serum. Subjective morphological evaluation by all three "blinded" hematopathologists, as well as AA and RH (not blinded) indi-

Table III. Effect of Depletion of Adherent Cells and T Cells on Cloning Efficiency of Hematopoietic Progenitor Cells from LDMNC in the Presence of No Addition (1), Nonimmune Serum (2), or Anti-PFR Antiserum (3)

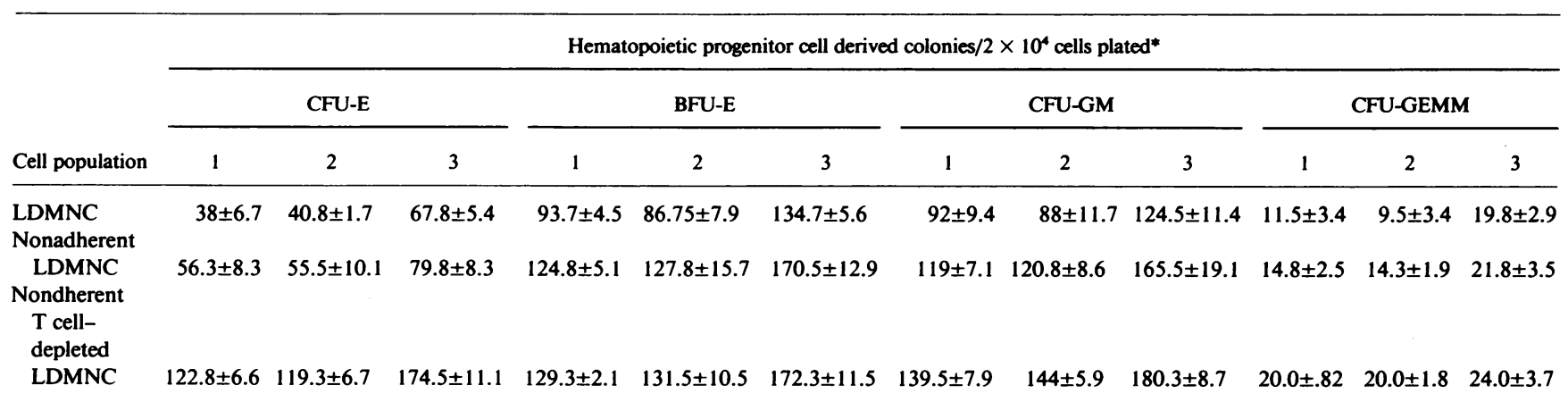

* Data are the mean \pm SD of four replicates. All cell populations are from the same individual. Statistical significance is discussed in Results. 
cated that anti-PFR antiserum (but not nonimmune serum)treated cells from CFU-E-derived colonies had megaloblastic features. When analyzed by cytophotometry, a greater number of CFU-E-derived normoblasts in anti-PFR antiserum-treated samples had a nuclear ploidy which was shifted toward $4 \mathrm{~N}$ or more when compared to cells developed in nonimmune serum (Fig. 4); furthermore a greater percentage of antiserum-treated cells appeared to possess more DNA per cell in $4 \mathrm{~N}$ than $2 \mathrm{~N}$ (Table IV). Microdensitometry also revealed that the average nuclear area of anti-PFR antiserum-treated cells was greater than nonimmune serum-treated cells $(P<0.001)$. In contrast, there was no difference in total RNA per cell among both groups. Thus, these objective findings indicative of increased DNA:RNA ratios correlated with our subjective (morphological) evaluation of megaloblastic changes induced by anti-PFR antiserum in vitro. This pattern of increased DNA:RNA ratios in anti-PFR antiserum-induced megaloblastic cells developed in vitro is very similar to that found in patients with megaloblastic bone marrows arising from folate/cobalamin deficiency (5).

Correlation of subjective and objective morphometric assessment of megaloblastic changes in BFU-E-derived cells. Because data with CFU-E-derived colonies indicated an anti-PFR antiserum-mediated induction of megaloblastosis, it strongly suggested that BFU-E-derived colonies developed in anti-PFR antiserum were also truly megaloblastic because these cells are in contact with antiserum in culture for $7 \mathrm{~d}$ longer. However, this remained to be further proven by objective data in light of the report by Reid et al. that megaloblastic changes are a feature of normal BFU-E-derived colonies during in vitro erythropoiesis (45). We therefore used objective morphometric parameters to determine if this correlated with our subjective ability to reproducibly distinguish "gross" from "lesser" megaloblastic changes under basal conditions of exposure to antiserum and nonimmune serum, respectively. The one-way analysis of

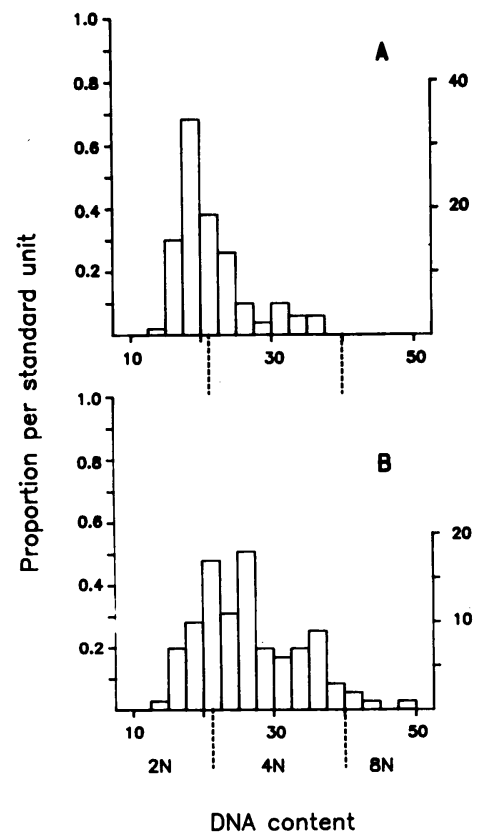

Figure 4. Histogram of DNA content of normoblasts from CFUE-derived colonies treated with nonimmune serum $(A)$ or anti-PFR antiserum (B) standardized by the $z$ sample standard 3 deviations. CFU-Ederived colonies were plucked,

$\rightarrow$ cytocentrifuged onto $\frac{\infty}{\bar{\omega}}$ glass slides, fixed, and DNA was stained with the Feulgen reaction. 100 CFU-E-derived normoblasts in each group were scanned and analyzed by cytophotometry as described in Methods. The ordinate on the left represents the proportion of cells as a function of DNA content expressed in arbitrary units on the abcissa.
Table IV. Microdensitometric Evaluation of DNA and RNA of Orthochromatic Normoblasts from CFU-E-derived Colonies Incubated with Nonimmune Serum and Anti-PFR Antiserum

\begin{tabular}{|c|c|c|c|}
\hline \multicolumn{2}{|l|}{ Parameter } & $\begin{array}{l}\text { Nonimmune } \\
\text { serum }\end{array}$ & $\begin{array}{l}\text { Anti-PFR } \\
\text { antiserum }\end{array}$ \\
\hline \multicolumn{2}{|l|}{ Mean total DNA per cell } & $21.63 \pm 5.02$ & $26.51 \pm 7.06^{\ddagger}$ \\
\hline \multicolumn{2}{|l|}{ Mean nuclear area $\left(\mu \mathrm{m}^{3}\right)$} & $163 \pm 51.6$ & $235 \pm 70.5^{\ddagger}$ \\
\hline \multirow[t]{3}{*}{ Nuclear ploidy (\% cells) } & $2 \mathrm{~N}$ & 50 & $17^{8}$ \\
\hline & $4 N$ & 50 & 79 \\
\hline & $8 \mathrm{~N}$ & - & 4 \\
\hline \multicolumn{2}{|c|}{ Mean total RNA per cell $(n=50)^{*}$} & $11.00 \pm 3.95$ & $10.59 \pm 3.09^{\prime \prime}$ \\
\hline
\end{tabular}

* Mean \pm SD per cell in arbitrary units.

${ }^{\ddagger} P<0.001$ compared to nonimmune serum ( $t$ test).

' $P<0.001$ compared to nonimmune serum (chi-square analysis).

" $P=0.6$ compared to nonimmune serum ( $t$ test).

variance used to compare the mean BFU-E-derived normoblast cell diameters observed for the first eight experimental conditions listed in Table $\mathrm{V}$ provided a highly significant overall test statistic $(P<0.0001)$, thus rejecting the null hypothesis that the means for all eight groups were equal. Application of the Student-Newman-Keuls multiple comparison procedure to these means revealed that the anti-PFR antiserum-treated BFU-E-derived cells (experiment 6) had significantly greater normoblast cell diameters than all other experimental conditions, and no statistically significant difference existed between the means observed for all other experimental groups. A similar result was found for the percent of normoblasts having more than one nucleus when compared to all other experimental groups. Application of Hochberg's Bonferroni procedure (42) to the $P$ values obtained from the seven chi-square tests comparing experimental group 6 to all other groups provided a marginally significant result $(P=0.055)$, thus suggesting that this group had a larger percentage of normoblasts having more than one nucleus as compared to all other experimental groups. These data therefore strongly supported the conclusion that megaloblastic changes, as recognized subjectively, could also be objectively defined by reproducible simple methods in BFU-E-derived cells during in vitro erythropoiesis.

Temporal relationship between anti-PFR antiserum-mediated effects on cloning efficiency and megaloblastic changes. When LDMNC were plated in the presence of anti-PFR antiserum over varying periods of time, the proliferative response of hematopoietic progenitor cells was maximal when cells were in contact with anti-PFR antiserum within the first $8 \mathrm{~h}$ of incubation (Fig. 5). This proliferative response progressively decreased to levels similar to nonimmune serum-treated cells when LDMNC were deprived of exposure to anti-PFR antiserum for over $24 \mathrm{~h}$. Evaluation of cell viability of LDMNC incubated over $24 \mathrm{~h}$ at $4^{\circ} \mathrm{C}$ indicated no change compared to time-zero (i.e., $>98 \%$ viable). This ruled out the potential for mononuclear cells to undergo autolysis, which could possibly account for less mononuclear cell-mediated induction of precursor cell proliferation (45) during in vitro hematopoiesis. Although the proliferative response was lost when the duration between incubation of cells and anti-PFR antiserum was delayed for $>24 \mathrm{~h}$, the cells from these BFU-E-derived colonies 
Table V. Representative Study on Effect of Addition of Various Agents in Modulating the Cloning Efficiency of BFU-E-and CFU-E-derived Colonies and Megaloblastic Expression of BFU-E-derived Cells during In Vitro Erythropoiesis

\begin{tabular}{|c|c|c|c|c|}
\hline \multirow[b]{2}{*}{$\begin{array}{l}\text { Addition to } \\
\text { culture }\end{array}$} & \multicolumn{2}{|c|}{$\begin{array}{l}\text { Morphometric analysis of BFU-E-derived } \\
\text { colonies }\end{array}$} & \multicolumn{2}{|c|}{ Cloning efficiency ${ }^{\ddagger}$} \\
\hline & $\begin{array}{l}\text { Normoblast } \\
\text { diameter* }\end{array}$ & $\begin{array}{l}\text { Normoblasts having } \\
>1 \text { nucleus }\end{array}$ & $\begin{array}{c}\text { CFU-E-derived } \\
\text { colonies } / 5 \times 10^{4} \text { cells }\end{array}$ & $\begin{array}{c}\text { BFU-E-derived } \\
\text { colonies } / 5 \times 10^{4} \text { cells }\end{array}$ \\
\hline & $\mu m$ & $\%$ & & \\
\hline No addition & $22.06 \pm 5.23$ & 2 & 122 & 72 \\
\hline Rabbit nonimmune serum & $23.10 \pm 4.71$ & 5 & 116 & 48 \\
\hline Rabbit nonimmune serum plus PFR & $22.96 \pm 6.70$ & 3 & 103 & 54 \\
\hline Rabbit nonimmune serum plus $2.8 \mathrm{mM}$ folic acid & $22.79 \pm 6.03$ & 4 & 84 & 46 \\
\hline \multicolumn{5}{|l|}{ Rabbit nonimmune serum plus PFR plus $2.8 \mathrm{mM}$} \\
\hline folic acid & $22.96 \pm 7.01$ & 2 & 73 & 46 \\
\hline Rabbit anti-PFR antiserum & $29.82 \pm 6.10^{\S}$ & $14^{8}$ & $206^{5}$ & $125^{8}$ \\
\hline Rabbit anti-PFR antiserum plus PFR & $23.61 \pm 4.70$ & 4 & 90 & 80 \\
\hline Rabbit anti-PFR antiserum plus $2.8 \mathrm{mM}$ folic acid & $21.97 \pm 6.42^{8}$ & $4^{8}$ & $165^{\S}$ & $118^{\S}$ \\
\hline \multicolumn{5}{|l|}{ Rabbit anti-PFR antiserum plus PFR $+2.8 \mathrm{mM}$} \\
\hline folic acid & $22.37 \pm 5.91$ & 5 & 82 & 76 \\
\hline Rabbit anti-glycophorin antiserum & $22.25 \pm 4.73$ & 3 & 85 & 71 \\
\hline Rabbit anti-platelet glycoprotein antiserum & - & - & 71 & - \\
\hline
\end{tabular}

All studies done on a single normal volunteer's bone marrow aspirate. Comparable results were obtained on three different occasions with different normal human volunteers. ${ }^{*}$ Each value represents the mean \pm SD of 100 orthochromatic normoblasts composing erythropoietic bursts in each treatment group. ${ }^{\ddagger}$ Each value represents the mean of duplicate samples. Routinely, there was $<10 \%$ deviation from the mean in duplicates from a single individual with each variable. ${ }^{8}$ Statistical analysis is discussed in Results.

were nevertheless megaloblastic when analyzed on day 14. Thus, these data suggested that the anti-PFR antiserum-induced stimulus for a cell-proliferative response within the first $24 \mathrm{~h}$ was unrelated to the events causing megaloblastic changes which required prolonged ( $14 \mathrm{~d}$ ) incubation with anti-PFR antiserum.

Subsequent studies were carried out to determine if the presence of anti-PFR antiserum over the entire culture period (14 d) was essential to the cell proliferative and megaloblastic response in progenitor cell-derived colonies. As shown in Fig. 6, when anti-PFR antiserum was incubated with LDMNC for varying periods and excess unbound antisera was washed out of the sample before plating, we found that the proliferation response in progenitor cell-derived colonies was evident if progenitor cells were in contact with anti-PFR antiserum for even $0.5 \mathrm{~h}$; the colony counts were consistently at least 1.5 -fold higher when compared to nonimmune serum-treated cells. With increasing duration of exposure to anti-PFR antiserum, the number of colonies increased to twofold higher than controls and was maintained when LDMNC were exposed to antiserum over the entire 24-h period. Examination of the morphology of orthochromatic normoblasts from BFU-E-derived colonies under these conditions (day 14) revealed that in spite of the overall higher cell proliferative response (colonies per plate and cells per colony), the cells were not megaloblastic. Thus, after short-term antibody interaction with hematopoietic progenitor cells, there was a proliferative stimulus which was triggered which gave anti-PFR antiserum-treated cells a growth advantage over cells exposed to nonimmune serum alone. Furthermore, this growth advantage was not dependent on the development of intracellular folate deficiency because the resulting cells were not megaloblastic.
The corollary to these studies was to determine the effect of negating anti-PFR antiserum-induced (expected) megaloblastic changes on the antiserum-induced cell proliferation response under conditions where antiserum was retained in culture during the entire $14 \mathrm{~d}$ in the presence of excess extracellular folate (Table V). The last two columns of Table $\mathrm{V}$ present the mean number of CFU-E- and BFU-E-derived colonies for each experimental condition. One-way analysis of variance applied to the CFU-E data rejected the null hypothesis of equal means for all 11 experimental conditions $(P<0.003)$. The Student-Newman-Keuls multiple comparison procedure indicated that the mean value observed for experimental group 6 was significantly different from that observed for all other experimental groups except group 8 . The only other significantly different comparison was between group 8 and groups 4, 5, 7, 9,10 , and 11 . There was no difference in the means observed for all other pairs of experimental groups. Similar results were found in the analysis of the BFU-E data listed in Table V, $P$ $<0.001$ for the overall analysis of variance and no difference was found between groups 6 and 8 . However, the StudentNewman-Keuls procedure indicated that 6 and 8 were different from all other experimental groups, and groups 7 and 9 were different from groups 2,4 , and 5 . There was no difference in the means observed for all other pairs of experimental groups. Taken together, these data strongly support the conclusion that despite the presence of excess anti-PFR antiserum, when the extracellular folate concentration was approximately 500 -fold higher than control samples, there was complete inhibition of the expected megaloblastic response without a change in the proliferative response.

Fig. 7 reveals that the cell proliferation effect of anti-PFR antiserum-treated cells exposed to $\left[{ }^{3} \mathrm{H}\right]$ thymidine was parallel 


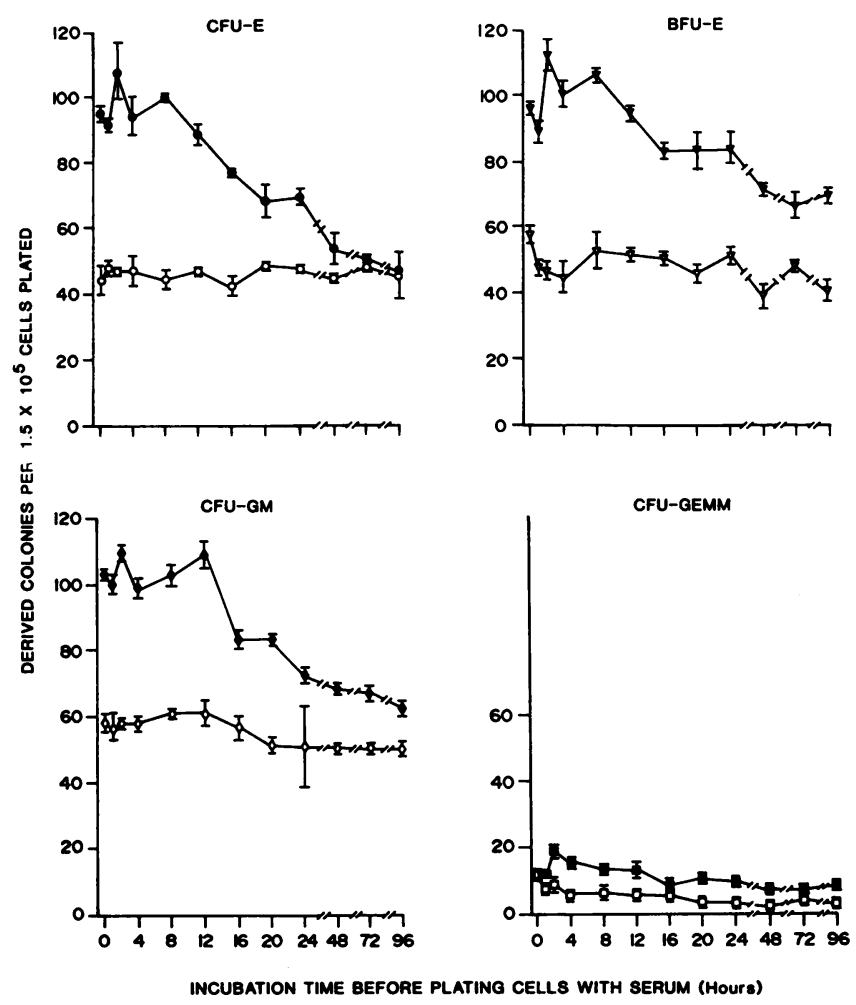

Figure 5. Effect of delaying incubation of LDMNC with anti-PFR antiserum (solid symbols) and nonimmune serum (open symbols) on cloning efficiency of CFU-E-, BFU-E-, CFU-GM-, and CFUGEMM-derived colonies. Time zero = isolation of LDMNC. The cells were plated in the presence of sera retained during development of progenitor cell-derived colonies ( $14 \mathrm{~d}$ ). Each point represents the mean $\pm \mathrm{SE}$ of duplicate studies on a single individual's LDMNC. to the (control) curve generated in the presence of anti-PFR antiserum alone, albeit at a lower proliferative capacity. Had the early proliferative signal predominantly involved a cohort of progenitor cells which were abruptly recruited into the $S$ phase of cell cycle, one would have expected that this cohort of early proliferating cells would have been irradiated due to significant incorporation of $\left[{ }^{3} \mathrm{H}\right]$ thymidine into DNA; this was not the case.

\section{Discussion}

The two observed effects after the interaction of anti-folate receptor IgG antibodies with hematopoietic progenitor cells during in vitro hematopoiesis (megaloblastosis and increased cell proliferation) were consistently quenched when antibody was preincubated with PFR (22). These findings were highly suggestive of the specificity of anti-PFR IgG antibody interaction with FBPs on the surface of LDMNC, especially in light of the apparent homogeneous nature of the antigen [PFR] (7) and the specific interaction exhibited by the antibody to apo- and holoFBPs from various human tissues $(7-13,15,19,21,46,47)$. However, these data still did not rule out the additional possibility that the antiserum may have reacted with a second distinct, functionally-unrelated moiety on the surface of LDMNC which possessed surface carbohydrate structures which were similar to PFR, and when recognized by anti-PFR antiserum, gave rise to a stimulus for cell proliferation. However, the identification of a single iodinated species at $M_{\mathrm{r}} 44,000$ (similar to folate receptors) which was specifically immunoprecipitated by crude and purified anti-PFR IgG ruled out this possibility. While we failed to identify another cross-reacting iodinated species on LDMNC, these data still do not rule out another nonprotein component which reacted with anti-PFR IgG; we
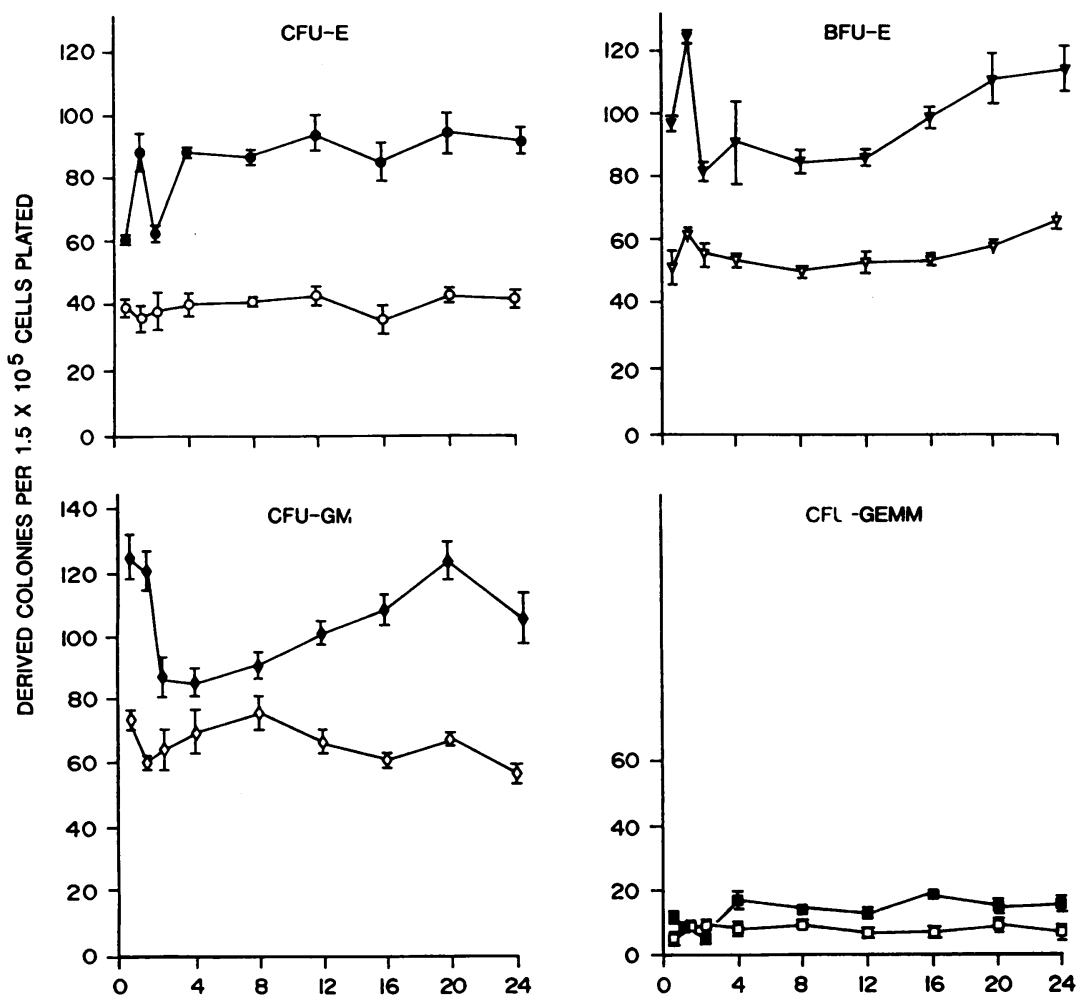

INCUBATION TIME WITH SERUM BEFORE CELL WASH AND PLATING (Hours)
Figure 6. Effect of incubation of LDMNC with anti-PFR antiserum (solid symbols) or nonimmune serum (open symbols) for various times before washing and plating cells in the absence of serum under optimal conditions for the generation of CFU-E-, BFU-E-, CFU-GM-, and CFU-GEMM-derived colonies. Each point represents the mean $\pm \mathrm{SE}$ of duplicate studies on a single individual's LDMNC. 


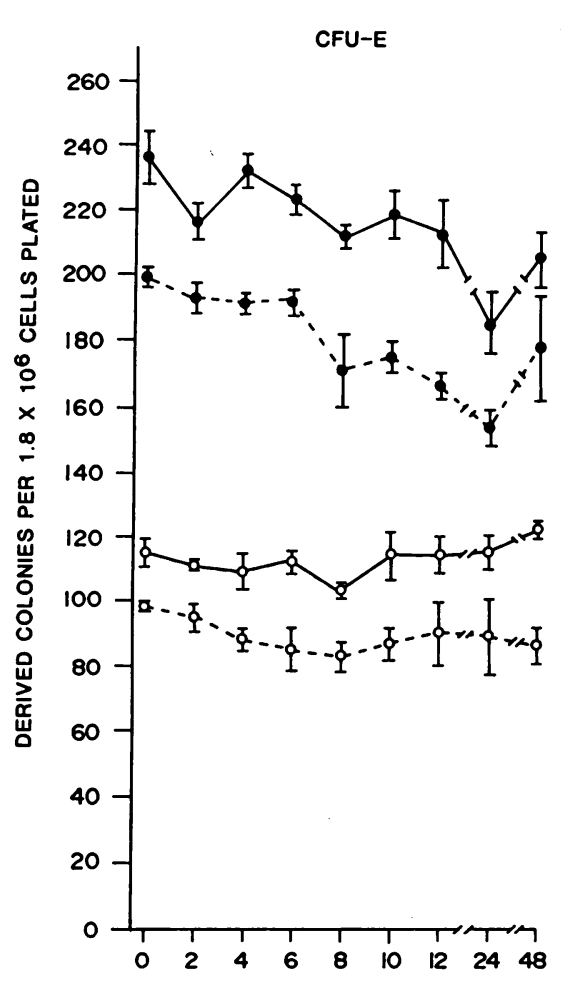

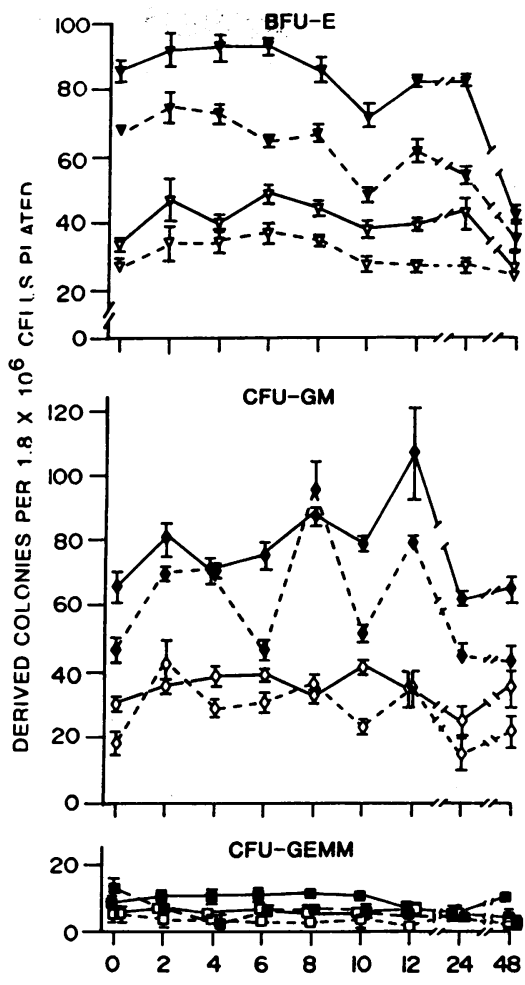

INCUBATION TIME WITH SERUM BEFORE EXPOSURE TO [3 $\left.\mathbf{3}_{H}\right]$ THYMIDINE (HOUIS)
Figure 7. Effect of duration of incubation of LDMNC with anti-PFR antiserum (solid symbols) and nonimmune serum (open symbols) before exposure to $\left[{ }^{3} \mathrm{H}\right]$ thymidine alone (broken lines) or unlabeled thymidine (solid lines). Cells were subsequently washed and cultured under optimal conditions for the generation of CFU-E-, BFU-E-, CFU-GM-, and CFU-GEMM-derived colonies. Each point represent the mean \pm SE of duplicate studies on a single individual's LDMNC. are, however, unaware of any other data that supports such a possibility. When taken together, our studies strongly implicated anti-PFR IgG interaction with folate receptors on LDMNC. Thus, any effect(s) stemming from anti-PFR antibody interaction with hematopoietic progenitor cells were likely related to interaction with cell surface folate receptors.

The earlier conclusion that anti-PFR antiserum induced a significant cell proliferative stimulus in BFU-E-derived cells (22) has been extended to other progenitor cell (CFU-E-, CFUGM-, and CFU-GEMM-) derived colonies from a cohort of normal human subjects, which indicate that multiple hematopoietic lineages also possess cell surface folate receptors. Taken together with earlier in vitro studies which show that $(a)$ human bone marrow cells accumulated folates $(48,49)$, and $(b)$ folate transport proteins (receptors) on KB cell membranes (13) are also methotrexate-binding proteins $(15,47)$, our data strongly support the possibility for accumulation of folates and folate analogues through functional folate receptors on bone marrow-derived cells $(48,49)$. We had earlier cautioned that the in vitro model of anti-PFR antiserum-induced folate deficiency demonstrated for BFU-E-derived colonies (22) could be the result of anti-PFR antiserum interacting either with hematopoietic progenitor cells or accessory cells which are important for the growth of these progenitor cells in vitro. However, the identification of similar FBPs in erythrocyte $(20,21)$ and granulocyte membranes (50), and the effect of antiserum on cloning efficiency of nonadherent LDMNC as well as nonadherent $\mathrm{T}$ cell-depleted LDMNC-derived colonies now strongly support a direct effect of anti-PFR antiserum on folate receptors on these hematopoietic progenitor cells.

The term "megaloblastic changes" describes the morphological expression (nuclear:cytoplasmic asynchrony) of events occurring at the biochemical level, where DNA synthesis is in- complete, whereas RNA synthesis remains unaffected. Whereas megaloblastic changes have not been objectively studied in great depth, it has been documented that increased DNA:RNA ratios in orthochromatic megaloblasts obtained from folate/cobalamin-deficient patients correlates well with subjective morphological assessment of megaloblastic changes (5). In this paper, we have confirmed that our subjective and objective parameters indicative of megaloblastic changes also correlated with altered DNA:RNA ratios in various experimental groups involving anti-PFR antiserum and nonimmune serum during in vitro erythropoiesis. Significantly, our data on CFU-E-derived cells indicated that anti-PFR antiserumtreated cells had DNA:RNA ratios which were significantly higher than nonimmune serum-treated cells. Furthermore, we have rigorously tested the hypothesis that anti-PFR antiseruminduced megaloblastic changes in BFU-E-derived colonies (as determined subjectively) can also be objectively demonstrated in a reproducible manner. These data, when taken together with our earlier study (22), constitute an experimental validation of the conclusion that morphological evaluation by our parameters was an appropriate method to assess megaloblastic changes during in vitro erythropoiesis. It should nevertheless be stressed that neither the concentration, nor form of folate, routinely used to assess in vitro hematopoiesis can be construed as directly reflective of physiological hematopoiesis in vivo. Moreover, the kinetics of uptake of specific nutrients by hematopoietic cells growing in semisolid (methylcellulose) versus liquid media are likely to be dissimilar due to differences in molecular interaction of nutrients with cells at the semisolid media:cell and liquid media:cell interphases. This could nevertheless explain the ability of anti-PFR antiserum to inhibit transport of folate into hematopoietic cells developing in semisolid media despite the unphysiologically high folate con- 
centrations used (22). Furthermore, the fact that raising the single variable of extracellular folate concentration in semisolid media led to a statistically significant abrogation of (expected) anti-PFR antiserum-induced megaloblastic changes supports this concept, and further emphasizes caution against comparing the extracellular folate concentration during in vitro hematopoiesis to physiological folate concentrations. Therefore, although the quantitation of megaloblastic changes in our model coincidentally correlates with megaloblastic changes in vivo in humans at the morphological, morphometric, and biochemical levels, final proof of the effect of anti-PFR antibodies on hematopoietic progenitor cells must await further studies using the intact animal.

The two anti-PFR antiserum-induced effects (increased cloning efficiency and megaloblastic changes) were dissociated from each other using different strategies. The first involved washing away the antiserum after initial contact with cells. This led to a proliferative effect, but due to the presence of folate in culture medium, and removal of antibody before plating, the resulting progenitor-derived cells were not megaloblastic. Conversely, when plating was delayed beyond $24 \mathrm{~h}$, the BFU-E-derived normoblasts were megaloblastic when antiserum was retained during culture; however, delayed plating led to loss of cell proliferative responses. Finally, while anti-PFR antiserum-induced megaloblastosis in BFU-E-derived colonies was negated by incorporating a 500 -fold excess of folic acid in methylcellulose during development of these cells (20), the antiserum-induced increase in cloning efficiency of BFU-E- and CFU-E-derived colonies was unaffected. Taken together, these studies underscore the fact that an early folate receptor-mediated response to interaction with folate receptor antibody culminates in increased cell proliferation, whereas during the entire duration of in vitro erythropoiesis, these folate receptors also serve to protect the cell from developing intracellular folate deficiency and megaloblastosis.

The identification that specific interaction of anti-PFR antibody with cell surface folate receptors leads to an early signal that culminates in cell proliferation was quite unexpected. In contrast, monoclonal antibodies to transferrin receptors led to intracellular iron deficiency and inhibition of growth of erythroid progenitors (51). Based on data presented in this paper, and that from other reports $(13,15-19,22,46,47)$, it appears that folate receptors are dynamically involved in cellular folate uptake and therefore constitutively have a "sustaining" influence on cell proliferation. Whether the "up"-regulation of folate receptors in experimental nutritional folate deficiency (19) leads to direct effects of hematopoietic progenitor and precursor cell hyperplasia remains to be shown. Our model of antiPFR antiserum-mediated induction of folate-deficient megaloblastic hematopoiesis in vitro strongly suggests that folate receptors may play a more active role in cell proliferation than previously recognized, and could somehow be involved in the hyperplastic bone marrow response in clinical folate deficiency. Recent studies suggest that folate receptors on brush border membranes of renal tubular cells (52) monkey kidney cells $(46,53)$ and KB cells $(54)$ are linked to glycosyl phosphatidylinositol (GPI) anchors. The observations that many antibodies to GPI-anchored proteins (55-57) induce a cell-proliferative response $(58,59)$ are reminescent of and could also explain our findings if folate receptors on hematopoietic cells are also GPI-anchored. These and related possibilities are currently under investigation in our laboratory.

\section{Acknowledgments}

We wish to thank Stephanie McGillem for expert secretarial support during the preparation of this manuscript, Timothy Guscar for purifying antibodies, and Dr. E. F. Srour for guidance in studies using the fluorescence activated cell sorter. We gratefully acknowledge helpful discussions with Drs. M. Dayton, A. Srivastava, and A. J. Zubrowka during the course of these studies.

This work was supported by grants \# RO1 HD 20889 and \# RO1 AA08307 from the National Institute of Child Health and Human Development and the National Institute on Alcohol Abuse and Alcoholism awarded to Dr. Antony.

\section{References}

1. Chanarin, I. 1979. The Megaloblastic Anemias. Blackwell Scientific Publications, Oxford, UK.

2. Beck, W. S. 1983. Metabolic aspects of vitamin $B_{12}$ and folic acid: the megaloblastic anemias. In Hematology. W. J. Williams, E. Beutler, A. J. Erslev,

R. W. Rundles, and M. A. Lichtman, editor. McGraw-Hill Book Co., New York. 301-331, 434-465.

3. Herbert, V. 1985. Megaloblastic anemias. Biology of disease. Lab. Invest. 52:3-19.

4. Wintrobe, M. M., G. R. Lee, D. R. Boggs, T. C. Bithell, J. Foerster, J. W. Athens, and J. N. Lukens. 1981. Megaloblastic and nonmegaloblastic anemia. In Clinical Hematology. Lea and Febiger, Philadelphia, PA 559-640.

5. Wickramasinghe, S. N., D. G. Chalmers, and E. H. Cooper. 1967. Disturbed proliferation of erythropoietic cells in pernicious anemia. Nature (Lond.) 215:189-191.

6. Parmley, R. T., M. Ogawa, S. S. Spicer, H. L. Bank, and N. J. Wright. 1978. Human marrow erythropoiesis in culture. III. Ultrastructural and cytochemical studies of cellular interactions. Exp. Hematol. 6:78-90.

7. Antony, A. C., C. S. Utley, K. C. VanHorne, and J. F. Kolhouse. 1981. Isolation and characterization of a folate receptor from human placenta. J. Biol. Chem. 256:9684-9692.

8. Antony, A. C., C. S. Utley, P. D. Marcell, and J. F. Kolhouse. 1982. Isolation, characterization and comparison of the solubilized particulate and soluble folate-binding proteins from human milk. J. Biol. Chem. 257:10081-10089.

9. Kane, M. A., P. C. Elwood, R. M. Portillo, A. C. Antony, and J. F. Kolhouse. 1986. The interrelationship of the soluble and membrane-associated folate-binding proteins in human KB cells. J. Biol. Chem. 261:15625-15631.

10. Antony, A. C., R. S. Verma, A. R. Unune, and J. A. LaRosa. 1989.

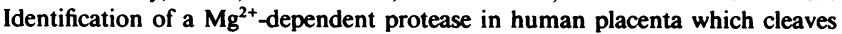
hydrophobic folate-binding proteins to soluble forms. J. Biol. Chem. 264:19111194.

11. Antony, A. C., R. S. Verma, and R. S. Kincade. 1987. Development of a specific radioimmunoassay for placental folate receptors and related high-affinity folate binding proteins in human tissues. Anal. Biochem. 162:224-235.

12. Antony, A. C., and R. S. Verma. 1989. Hydrophobic erythrocyte folate binding proteins are converted to hydrophilic forms by trypsin in vitro. Biochim. Biophys. Acta. 979:62-68.

13. Antony, A. C., M. A. Kane, R. M. Portillo, P. C. Elwood, and J. F. Kolhouse. 1985. Studies of the role of a particulate folate-binding protein in the uptake of 5-methyltetrahydrofolate by cultured human KB cells. J. Biol. Chem. 260:14911-14917.

14. McHugh, M., and Y. C. Cheng. 1979. Characterization of a high affinity folate binder in human cell membranes and its characterization in cultured human KB cells. J. Biol. Chem. 254:11312-11318.

15. Kane, M. A., R. M. Portillo, P. C. Elwood, A. C. Antony, and J. F. Kolhouse. 1986. The influence of extracellular folate concentration on methotrexate uptake by human KB cells. Partial characterization of a methotrexatebinding protein. J. Biol. Chem. 261:44-49.

16. Kamen, B. A., and A. Capdevila. 1986. Receptor-mediated folate accumulation is regulated by the cellular folate content. Proc. Natl. Acad. Sci. USA. 83:5983-5987.

17. Kamen, B. A., M. Wang A. J. Strekfuss, X. Peryea, and R. G. W. Anderson. 1988. Delivery of folates to the cytoplasm of MA 104 cells is mediated by a surface membrane receptor that recycles. J. Biol. Chem. 263:13602-13609.

18. Kamen, B. A., C. A. Johnson, M.-T. Wang and R. G. W. Anderson. 1989. Regulation of the cytoplasmic accumulation of 5-methyltetrahydrofolate in MA 104 cells is independent of folate receptor regulation. J. Clin. Invest. 84:13791386.

19. Kane, M. A., P. C. Elwood, R. M. Portillo, A. C. Antony, V. Najfeld, A. Finley, S. Waxman, and J. F. Kolhouse. 1988. Influence on immunoreactive folate-binding proteins of extracellular folate concentration on cultured human cells. J. Clin. Invest. 81:1398-1406.

20. Antony, A. C., M. A. Kane, S. R. Krishnan, R. S. Kincade, and R. S. 
Verma. 1989. Folate (pteroylglutamate) uptake in human red blood cells, erythroid precursors and $\mathrm{KB}$ cells at high extracellular folic acid concentrations: evidence against a role for specific folate-binding and transport proteins. Biochem. J. 260:401-411.

21. Antony, A. C., R. S. Kincade, R. S. Verma, and S. R. Krishnan. 1987. Identification of high affinity folate-binding proteins in human erythrocyte membranes. J. Clin. Invest. 80:711-723.

22. Antony, A. C., E. Bruno, R. A. Briddell, J. E. Brandt, R. S. Verma, and R. Hoffman. 1987. Effect of perturbation of specific folate receptors during in vitro erythropoiesis. J. Clin. Invest. 80:1618-1623.

23. Broxmeyer, H. E. 1982. Relationship of cell-cycle expression of Ia-like antigenic determinants on normal and leukemic human granulocyte-macrophage progenitor cells to regulation in vitro by acidic isoferritins. J. Clin. Invest. 69:632-642.

24. Wilchek, M., V. Bocchini, M. Becker, and D. Givol. 1971. A general method for the specific isolation of peptides containing modified residues, using insoluble antibody columns. Biochemistry. 10:2828-2834.

25. Livingston, D. M. 1974. Immunoaffinity chromatography of proteins. Methods Enzymol. 34:723-731.

26. Ảkerström, B., and L. Björek. 1986. A physicochemical study of protein $\mathrm{G}$, a molecule with unique immunoglobulin G-binding properties. J. Biol. Chem. 261:10240-10247.

27. Marchesi, S. L., and J. A. Chasis. 1979. Isolation of human platelet glycoproteins. Biochim. Biophys. Acta. 555:442-459.

28. Mazur, E. M., R. Hoffman, J. Chasis, S. Marchesi, and E. Bruno. 1981. Immunofluorescent identification of human megakaryocyte colonies using an anti-platelet glycoprotein antiserum. Blood. 57:277-286.

29. Marchesi, V. T., T. W. Tillack, R. L. Jackson, J. P. Segrest, and R. E. Scott. 1972. Chemical characterization and surface orientation of the major glycoprotein of the human erythrocyte membrane. Proc. Natl. Acad. Sci. USA. 69:14451449.

30. Tomita, M., and V. T. Marchesi. 1975. Chemical characterization and surface orientation of the major glycoprotein of the human erythrocyte membrane. Proc. Natl. Acad. Sci. USA. 72:2964-2968.

31. Lu, L., R. A. Briddell, C. D. Graham, J. E. Brandt, E. Bruno, and R. Hoffman. 1988. Effect of recombinant and purified human hematopoietic growth factors on in vitro colony formation by enriched populations of human megakaryocyte progenitor cells. Br. J. Haematol. 70:149-156.

32. Lu, L., H. E. Broxmeyer, P. A. Meyers, M. A. S. Moore, and H. T. Thaler. 1983. Association of cell cycle expression of la-like antigen determinants on normal human multipotential (CFU-GEMM) and erythroid (BFU-E) progenitor cells with regulation in vitro by acidic isoferritins. Blood. 61:250-256.

33. Fauser, A. A., and H. A. Messner. 1978. Granuloerythropoietic colonies in human bone marrow, peripheral blood and cord blood. Blood. 52:1243-1248.

34. Waxman, S., and C. Schreiber. 1980. Determination of folate by use of radioactive folate and binding proteins. Methods Enzymol. 66:468-483.

35. Mikel, U. V., W. N. Fisbein, and G. F. Bahr. 1985. Some practical considerations in quantitative absorbance microspectrophotometry. Preparation techniques in DNA cytophotometry. Anal. Quant. Cytol. Histol. 7:107-118.

36. Ritter, C., H. S. DiStefano, and A. Farah. 1961. A method for the cytophotometric estimation of ribonucleic acid. J. Histochem. Cytochem. 9:97-102.

37. Srour, E. F., T. Leemhuis, L. Jenski, R. Redmond, and J. Jansen. 1990 Cytolytic activity of human natural killer cell subpopulations isolated by fourcolor immunofluorescence flow cytometric cell sorting. Cytometry. 11:442-446.

38. Lowry, O. H., N. J. Rosebrough, A. L. Farr, and R. J. Randall. 1951 Protein determination with the folin phenol reagent. J. Biol. Chem 193:265-275.

39. Blakley, R. L. 1969. The Biochemistry of Folic Acid and Related Pteridines. John Wiley \& Sons, New York. 58-105.
40. Hicks, C. R. 1982. Fundamental Concepts in the Design of Experiments 3rd ed. CBC College Publishing, New York. 36-85.

41. Draper, N. R., and H. Smith. 1981. Applied Regression Analysis. John Wiley \& Sons, New York. 238.

42. Hochberg, Y. 1988. A sharper Bonferroni procedure for multiple tests of significance. Biometrika. 75:800-802.

43. Elwood, P. C. 1989. Molecular cloning and characterization of the human folate-binding protein cDNA from placenta and malignant tissue culture (KB) cells. J. Biol. Chem. 264:14893-14901.

44. Wickramasinghe, S. N. 1970. RNA content of megaloblasts in pernicious anemia. Scand J. Haematol. 7:398-400.

45. Reid, C. D. L., L. C. Baptista, R. Deacon, and I. Chanarin. 1981. Megaloblastic change is a feature of colonies derived from an early erythroid progenitor (BFU-E) stimulated by monocytes in culture. Br. J. Haematol. 49:551-561.

46. Rothberg, K. G., Y. Ying, J. F. Kolhouse, B. A. Kamen, and R. G. W. Anderson. 1990. The glycophospholipid-linked folate receptor internalizes folate without entering the clathrin-coated pit endocytic pathway. J. Cell Biol. 110:637649.

47. Deutsch, J. C., P. C. Elwood, R. M. Portillo, M. G. Macey, and J. F. Kolhouse. 1989. Role of the membrane-associated folate binding protein (folate receptor) in methotrexate transport by human KB cells. Arch. Biochem. Biophys. 274:327-337.

48. Hoffbrand, A. V., E. Tripp, D. Catovsky, and K. C. Das. 1973. Transport of methotrexate into normal hematopoietic cells and into leukemia cells and its effect on DNA synthesis. Br. J. Haematol. 25:497-511.

49. daCosta, M., and M. P. Iqbal. 1981. The transport and accumulation of methotrexate in human erythrocytes. Cancer (Phila.). 48:2427-2432.

50. daCosta, M., and S. P. Rothenberg. 1974. Appearance of a folate binder in leukocytes and serum of pregnant women who are pregnant or taking oral contraceptives. J. Lab. Clin. Med. 83:217-224.

51. Shannon, K. M., J. W. Larrick, S. A. Fulcher, K. B. Burck, J. Pacely, J. C. Davis, and D. B. Ring. 1986. Selective inhibition of the growth of human erythroid bursts by monoclonal antibodies against transferrin or the transferrin receptor. Blood. 67:1631-1638.

52. Lee, H. C., J. Selhub, and T. Rosenberry. 1989. Folate binding protein (FBP) in rat kidney has covalently bound phosphatidylinositol (PI) moiety which provides the sole anchoring domain to brush border membranes. FASEB (Fed. Am. Soc. Exp. Biol.) J. 3:4835. (Abstr.)

53. Lacey, S. W., J. M. Sanders, K. G. Rothberg, R. G. W. Anderson, and B. A. Kamen. 1989. Complementary DNA for the folate binding protein correctly predicts anchoring to the membrane by glycosyl-phosphatidylinositol. J. Clin. Invest. 84:715-720.

54. Luhrs, C. A. and B. L. Slomiany, 1989. A human membrane-associated folate binding protein is anchored by a glycosyl-phosphatidylinositol tail. J. Biol. Chem. 264:21446-21449.

55. Low, M. G. 1989. Glycosyl-phosphatidylinositol: a versatile anchor for cell surface proteins. FASEB (Fed. Am. Soc. Exp. Biol.) J. 3:1600-1608.

56. Low, M. G., and A. R. Saltiel. 1988. Structural and functional roles of glycosyl-phosphatidylinositol in membranes. Science (Wash. DC). 239:268-275.

57. Ferguson, M. A. J., and A. F. Williams. 1988. Cell surface anchoring of proteins via glycosyl-phosphatidylinositol structures. Annu. Rev. Biochem. 57:285-320.

58. Thompson, L. F., J. M. Ruedi, and M. G. Low. 1988. Activation of human peripheral blood T cells by antibodies to ecto-5' nucleotidase. FASEB (Fed. Am. Soc. Exp. Biol.) J. 2:A1653. (Abstr).

59. Ritter, A. R., L. S. Davis, S. S. Patel, J. P. Atkinson, and P. E. Lipsky 1988. An antiserum to decay accelerating factor (DAF) activates human $T$ cells. FASEB (Fed. Am. Soc. Exp. Biol.) J. 2:A871. (Abstr.) 